\title{
Coal Technology Program Progress Report for January 1977
}

\section{MASTER}

\section{OAK RIDGE NATIONAL LABORATORY}




\section{DISCLAIMER}

This report was prepared as an account of work sponsored by an agency of the United States Government. Neither the United States Government nor any agency Thereof, nor any of their employees, makes any warranty, express or implied, or assumes any legal liability or responsibility for the accuracy, completeness, or usefulness of any information, apparatus, product, or process disclosed, or represents that its use would not infringe privately owned rights. Reference herein to any specific commercial product, process, or service by trade name, trademark, manufacturer, or otherwise does not necessarily constitute or imply its endorsement, recommendation, or favoring by the United States Government or any agency thereof. The views and opinions of authors expressed herein do not necessarily state or reflect those of the United States Government or any agency thereof. 


\section{DISCLAIMER}

Portions of this document may be illegible in electronic image products. Images are produced from the best available original document. 


\section{Printed in the United States of America. Available from National Technical Information Service \\ U.S. Department of Commerce \\ 5285 Port Royal Road, Springfield, Virginia 22161 \\ Price: Printed Copy $\$ 4.50$; Microfiche $\$ 3.00$}

This report was prepared as an account of work sponsored by the United States Government. Neither the United States nor the Energy Research and Development Administration/United States Nuclear Regulatory Commission, nor any of their employees, nor any of their contractors, subcontractors, or their employees, makes any warranty, express or implied, or assumes any legal liability or responsibility for the accuracy, completeness or usefulness of any information, apparatus, product or process disclosed, or represents that its use would not infringe privately owned rights. 
Contract No. W-7405-eng-26

COAL TECHNOLOGY PROGRAM

PROGRESS REPORT FOR JANUARY 1977

Date: Published - March 1977

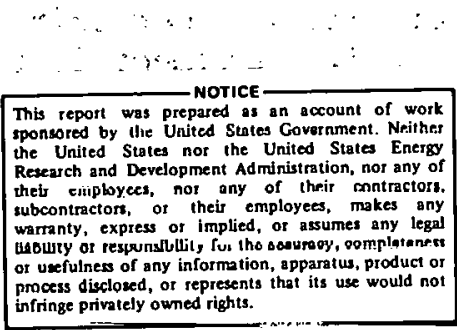

NOTICE This document contains information of a preliminary nature it is subject to revision or correction and therefore does not represent a final report.

OAK RIDGE NATIONAL LABORATORY

Oak Ridge, Tennessee 37830

operated by

UNION CARBIDE CORPORATION

for the

ENERGY RESEARCH AND DEVELOPMENT ADMINISTRATION 
ORNL/TM-5044, Progress Report for August 1974

ORNL/TM-5045, Progress Report for September 1974

ORNL/TM-5046, Progress Report for October 1974

ORNL/TM-4787, Progress Report for November 1974

ORNL/TM-4796, Progress Report for December 1974

ORNL/TM-4850, Progress Report for January 1975

ORNL/TM-4873, Progress Report for February 1975

ORNL/TM-4892, Progress Report for March 1975

ORNL/TM-4946, Progress Report for April 1975

ORNL/TM-4966, Progress Report. for May 1975

ORNL/TM-5010, Progress Report for June 1975

ORNL/TM-5037, Progress Report for July 1975

ORNL/TM-5092, Progress Report for Augist 1975

ORNL/TM-5124, Progress Report for September 1975

ORNL/TM-5186, Progress Report for October 1975

ORNL/TM-5214, Progress Report for November 1975

ORNL/TM-5246, Progress Report for December 1975

ORNL/TM-5301, Progress Report for January 1976

ORNL/TM-5321, Progress Report for February 1976

ORNL/TM-5430, Progress Report for March 1976

ORNL/TM-5479, Progress Report for April 1976

ORNL/TM-5532, Progress Report for May 1976

ORNL/TM-5595, Progress Report for June 1976

ORNL/TM-5611, Progress Report for July 1976

ORNL/TM-5654, Progress Report for August 1976

ORNL/TM-5674, Progress Report for September 1976

URNL/TM-5717, Progress Report for October 1976

UKNL/TM-5752, Progress Report for November 1976

ORNL/TM-5770, Progress Report for December 1976 
Abstract ............................... . . . . . 1

1. Summary .... . . . . . . . . . . . . . . . . . 1

2. Coal Conversion Process Development ... . . . . . . . . . . . . 3

2.1 Hydrocarbonization Research . . . . . . . . . ........ 3

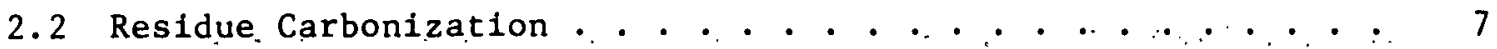

2.3 Experimental Engineering Support of an In Situ
Gasification Process . . . . . . . . . . . . . 13

2.4 Coal-Solvent-Hydrogen Mixing . . . . . . . . . . . . . 13

2.5 Pressurized Carbonization of Residue .................. . . 14

3. Materials Engineering . . . . . . . . . . . . . . . . . 15

3.1 Pressure Vessel and Piping and Technology Assessment . . . 15

3.2 Inspection Techniques, for Wear- and $: \ddots_{1} \quad \ldots \ldots \ldots$ Process-Resistant Coatings . . . . . . . . . . 16

3. 3 Iron and Nickel Carbonyl Formation and Prevention . . . . . 17

3.4 Development of Techniques for Welding and

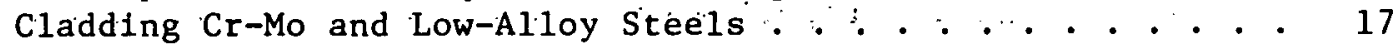

3.5 Prestressed Concrete Pressure Vessel Studies . . . . . . . 17.

3.6 Fluidized Bed Combustion . ................. . . 18

4. Alkall Metal Vapor Topping Cycles . . . . . . . . . . . . . . 19

4.1. Potassium Vapor Topping Cycle... . . . . . . . . . . . . 19

4.2 Coal-Fired Alkali Metal . . . . . . . . . . . . . 20

5. Critical Components Test Facility . . . . . . . . . . . . . 22

6. Engineering Studies and Technical Support . . . . . . . . . . 23

6.1 Process Modeling Support . . . . . . . . . . . . . . . 23

6.2 Process Research Digest. . . . . . . . . . . . . . . 23

6.3 Survey of Industrial Coal Conversion

6.4 Large Air Separation Plant Study . . . . . . . . . . . 29 
Page

7. Process and Program Analysis . . . . . . . . . . . . . . . 31

7.1 Low Btu Gasification . . . . . . . . . . . . . . . . . . 31

7.2 Direct Combustion . . . . . . . . . . . . . . . . 33

7.3 Advanced Power Conversion Systems . . . . . . . . . . . . 33

7.4 Liquefaction . . . . . . . . . . . . . . . . . . . . 39

7.5 High Btu Gasification. . . . . . . . . . . . . . . . . . 39

7.6 Gas Cleanup Studies . . . . . . . . . . . . . . . . 39

7.7 Beneficiation . . . . . . . . . . . . . . . 40

7.8 In Situ Coal Gasification . . . . . . . . . . . . . . 40

7.9 Potential for the Synthesis of Chemicals

from Coal and Oil Shale... . . . . . . . . . . . . 41

8. Fossil Energy Environmental Project . . . . . . . . . . . . . . . 44

8.1 Program Plan . . . . . . . . . . . . . . . . . . . . . . 44

8.2 Environmental Inclusions in RFPs ... . . . . . . . . . . . 44

8.3 Landfill Storage of Solid Wastes . . . . . . . . . . . . 44

8.4 Environmental Monitoring Handbook . . . . . . . . . . . . . . 44

8.5 Programmatic EIS-Pipeline Gas . . . . . . . . . . . . 45

9. Coal-Fueled MIUS . . . . . . . . . . . . . . . . . . . 46

9.1 Coal Metering and Feed Systems . . . . . . . . . . . . . 46

9.2 Supplemental Studies. . . . . . . . . . . . . . . . . . . . 46

10. Analytical Chemistry . . . . . . . . . . . . . . . . 47 
COAL TECHNOLOGY PROGRAM PROGRESS REPORT FOR JANUARY 1977

\begin{abstract}
This report - the thirtieth of a series - is a compendium of monthly progress reports for the ORNL research and development programs that are in support of the increased utilization of coal as a source of clean energy. The projects reported this month include those for coal conversion process development; materials engineering, alkali metal vapor topping cycles, a critical components test facility, engineering and support studies, process and program assistance, environmental assessment studies, coal-fueled MIUS, and analytical chemistry. $\cdots$
\end{abstract}

$\therefore \therefore:$
$\therefore: \therefore s$

1. SUMMARY

J. P. Nichols

Highlights of our progress in January are as follows:

Two runs were completed in our hydrocarbonization bench scale system during January, $\mathrm{HC}-10$ and $\mathrm{HC}-11$. Run $\mathrm{HC}-10$ was terminated after $10 \mathrm{hr}, 37$ min coal feed at $4.4 \mathrm{lb} / \mathrm{hr}$ because of difficulties in maintaining coal flow from the feed hopper. Run $\mathrm{HC}-11$ was terminated after $2 \mathrm{hr}$ coal feed at $10.0 \mathrm{lb} / \mathrm{hr}$ because of insufficient $\mathrm{H}_{2}$ and $\mathrm{N}_{2}$ supply pressure. A process evacuation alarm and additional experiment area lighting installations were completed.

- Two runs were made in the atmospheric carbonizer using Illinois No. 6 coal, and a third run was made to devolatilize char from the hydrocarbonization experiment. Some crafts work was done for the project and three sets of analytical data from previous work were received.

- Block pyrolysis experiments were begun utilizing eastern bituminous coal from the Pricetown, West Virginia, area. Results are significantly different from those obtained in past experiments with western subbituminous coals.

- Studies of liquid mixing in coal-solvent hydrogenation reactors continued as part of our Coal-Solvent-Hydrogen Mixing project. A series of residence-time, liquid hold-up, and pressure drop measurements was completę for afr and clean water flowing cocurrently upward through a bed packed with 4-mm-diam glass spheres. A Kenics in-line mixer was ordered for testing as an alternate reactor.

- In our project to investigate the pressurized carbonization of residue, we continued the installation of experimental equipment with expectations of beginning shakedown tests by late february. 
- The piping and pressure vessel project has experimental work in progress to determine the effects of heat treatment on thick $21 / 4 \mathrm{Cr}-1 \mathrm{Mo}$ plate.

- A FY 1977 work statement for inspection techniques for wear- and process-resistant coatings was completed. We are assembling a comprehensive technical report on plasma-sprayed coating inspection. We are ready to install our new $x$-ray fluorescence measuring system; delivery has been delayed by minor equipment problems and the gas shortage. Thermal experiments with ceramic coatings have not been successful. Eddy current work is progressing satisfactorily. Modifications to our high voltage probe recording system are still in progress.

- Experimental deposition of Alloy 20 ladding on carbon and lowalloy steels, and testing for cracking and microfissuring is in progress.

- During this reporting period, an eddy current inspection system has been designed and fabricated and will be used for the inspection of the surveillance test tubes previously subjected to a 500-hr exposure in a fluidized bed coal combustor environment.

- In our gas-fired potassium boiler work, the vapor separator was installed to complete the water test, but testing has been delayed because of the cutoff of natural gas. Work has continued on the design and fabrication of components for tests with potassium.

- The parametric cycle analysis of the plant and the analysis of the metal vapor turbine designs for the fluidized bed coal-tired alkali metal vapor topping cycle project was completed this month.

- The report on preliminary conceptual design studies of the component test modules will be forwarded to ERDA/FE following the reviews at ORNL and ERDA/ORO. No further progress on the Critical Components Test Facility work is expected until the survey by another contractor is completed.

- Engineering studies and technical support continued with work on process modeling, the process research digest, a survey of industrial equipment capabilities, and a study of large air separation plants.

- Process and program analysis studies are being conducted for the ERDA/FE Office of Program Planning and Analysis. This effort includes research studies on most of the coal conversion and utilization processes. The program objective is to provide, on a consistent basis, technical and economic evaluations of competing processes and systems for coal conversion and utilization.

- The writing stage is now complete and final editing is underway on the second major deliverable in our Fossil Energy Environmental Project. This is an information assessment on landfill storage of coal conversion solid wastes.

- In our coal-Fueled MIUS project, the coal feed system was modified and successfully placed on automatic operation to continue long-term endurance testing. Preliminary results of corrosion tests by Fluidyne were received and used to select the specimens for metallographic examination. A draft report was completed, and distributed for review, on tests of heat transfer rates from a fluidized bed to air-cooled tubes within the bed. Measured heat transfer coefficients were found to be significantly higher than those predicted by published correlations. 


\section{COAL CONVERSION PROCESS DEVELOPMENT}

J. R. Hightower, Jr.

Coal conversion process development activities are carried out in the Chemical Technology Division. This section discusses hydrocarbonization studies in a 20-atm bench-scale facility, studies of residue carbonization in an atmospheric pressure carbonizer and in a pressurized carbonizer, engineering support studies for in situ gasification, and studies for identifying and characterizing alternate reactor concepts for coal hydroliquefaction.

\subsection{Hydrocarbonization Research}

P. R. Westmoreland, C. H. Brown, G. E. Oswald, J. B. Gibson, : J. Beams, J. C. Rose, and R. Andrews

\subsubsection{Bench Scale System}

Design and Review. There was no effort to be reported in this area during January.

Fabrication and Installation. A process evacuation alarm (PEA) was, interconnected with the existing fire horns. The horns will now be actuated by automatic shutdowns and by a panel mounted button. The alarm can be cancelled by another panel mounted button. The PEA was deemed necessary to notify persons inside of Building 2528, but not in the control room, that they should vacate the building.

Three explosion-proof incandescent lamps were installed in the experiment room. Prior to this the illumination in the experiment area was poor.

A thermocouple was installed on the effluent pressure control valve body and the valve heating tape variac was installed in the control panel. The valve temperature is recorded on TR-5. This arrangement for controling the valve body temperature should prevent rough valve operation caused by ice formation.

The scrubber pump seals have been modified to prevent leakage. During run $\mathrm{HC}-1 \mathrm{l}$ the leak rate into the scrubber system was $\sim 1 \mathrm{gm} / \mathrm{hr}$. 'Ihis is a substantial reduction from HC-10. The new replacement seals for the pump have arrived.

Operation. Two runs were made during January--HC-lO and HC-ll. Preliminary material balance and effluent gas analyses are presented in Tables $2.1,2.2$, and 2.3.:

For run HC-10 coal was fed for $10 \mathrm{hr} 37 \mathrm{~min}$ at a rate of $4.4 \mathrm{lb} / \mathrm{hr}$. The low feed rate was caused by periodic plugs in the feed hopper cone. Too many fines in the feed coal ( $36 \%<140$ mesh) were responsible for the 
Table 2.1. Prelininary material balance for Experiment HC-_O

hverage jed temperature: $1050^{\circ} \mathrm{F}$

Total pressure: $300 \mathrm{psig}$

Coal feed rate

$\mathrm{H}_{2}$ feed rate: 213 std $\mathrm{ft}^{3} / \mathrm{ib}$ maf coal

As-received: $4.4 \mathrm{lb} / \mathrm{h}=$

Mo:sture-and-ash-free: $3.8 \mathrm{lb} / \mathrm{hr}$

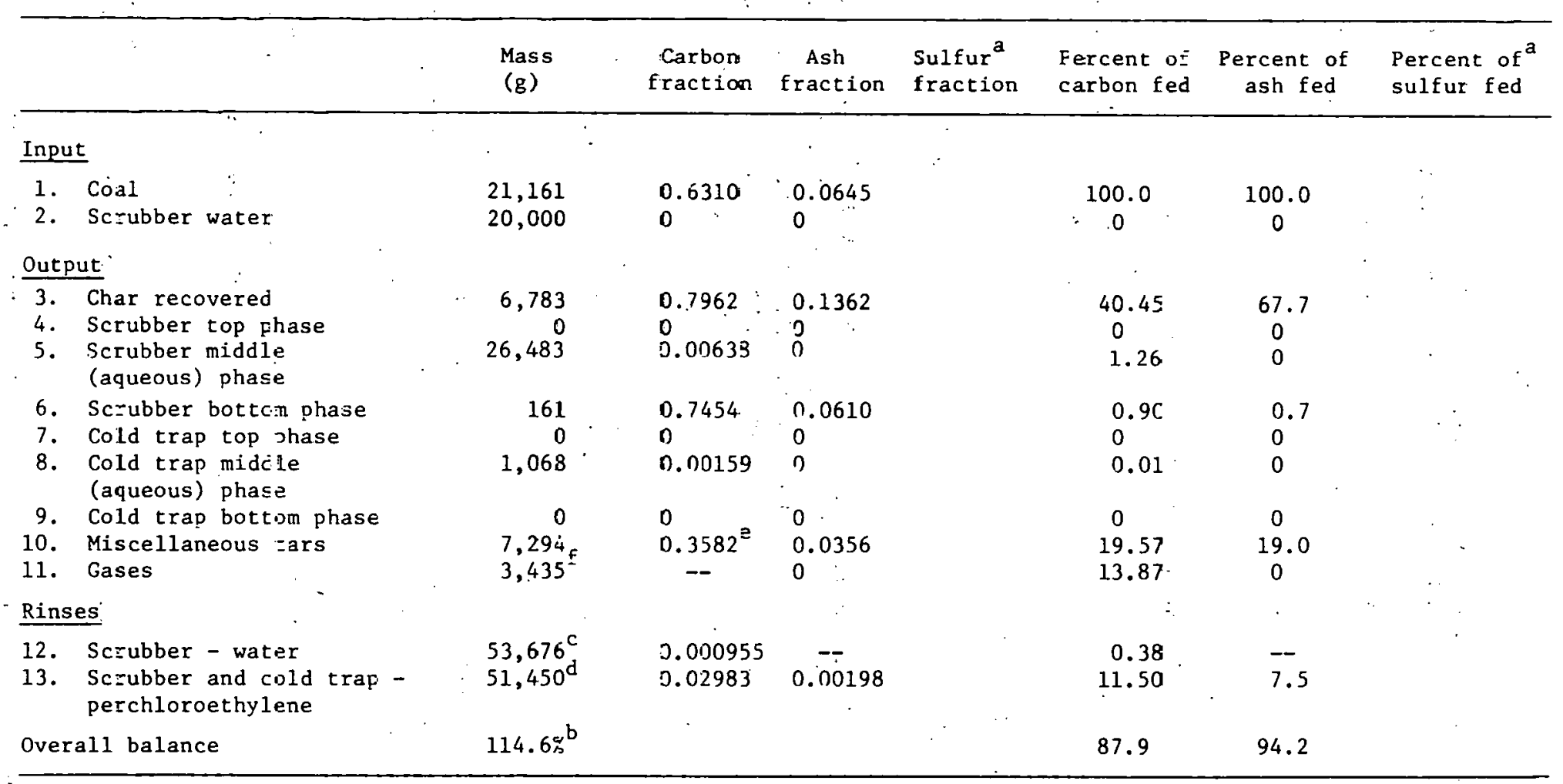

apending analytical results

$\mathrm{b}_{\text {Includes influx of water through scrubber purp seal }}$

${ }^{c} 7.33 \%$ residue

$d_{0.33 \%}$ residue

Resubmitted for analysis

${ }^{f}$ Does not include first hour of operation during which the gas chroratograph diaphram pump was inoperative 
Table 2.2. HC-IO average effluent gas composition ${ }^{a}$

\begin{tabular}{|c|c|c|c|}
\hline Component & $\begin{array}{l}\text { Effluent } \\
\text { rate (scfm) }\end{array}$ & $\begin{array}{c}\text { Compos ition } \\
(\%)\end{array}$ & $\begin{array}{l}\mathrm{H}_{2} \text { and } \mathrm{N}_{2}-\mathrm{free} \\
\therefore \ldots \text { composition }(\%)\end{array}$ \\
\hline $\mathrm{CH}_{4}$ & 0.100 & 0.78 & $\therefore \quad \therefore$ 50.8. $\therefore$ \\
\hline $\mathrm{C}_{2}$ & 0.025 & 0.20 & 12.7 \\
\hline$c_{3}$ & 0.004 & 0.03 & $\because 2.0$ \\
\hline $\mathrm{CO}$ & 0.041 & 0.32 & $\therefore \quad 20.8 \ldots \ldots$ \\
\hline $\mathrm{CO}_{2}$ & 0.006 & 0.05 & $\therefore \ldots 3.0$ \\
\hline $\mathrm{H}_{2} \mathrm{~S}$ & 0.021 & 0.16 & $\because \ldots,: 10 \cdot 7, \ldots$ \\
\hline $\mathrm{H}_{2}$ & 12.29 & .96 .37 & $\therefore \quad \because \cdot \cdots$ \\
\hline $\mathrm{N}_{2}$ & $\frac{.0 .266}{12.753}$ & $\begin{array}{c}2.09 \\
\quad: \cdots\end{array}$ & $\begin{array}{cccccc}\cdots & \cdots & \cdots & - & \cdots & \cdots \\
\cdots & \vdots & \ddots & \ddots & \cdots & .\end{array}$ \\
\hline
\end{tabular}

$a_{\text {Steady state composition is not reported because fluctuating }}$ coal feed rate prevented attainment of steady state. 
Table 2.3. Summary of preliminary material balances for Experiment $\mathrm{HC}-10$

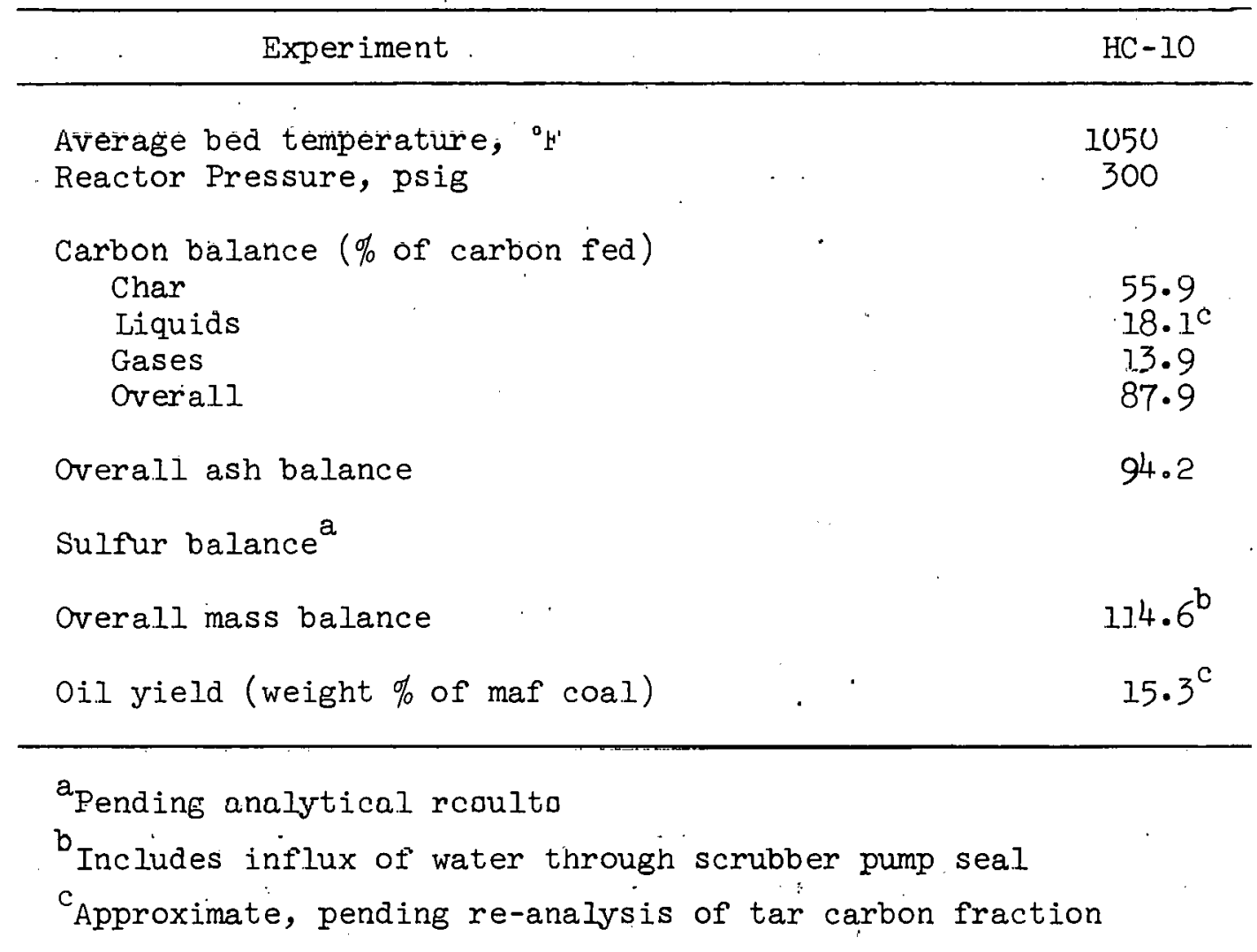


plugging condition. Feeds for previous successful runs were . $20 \%<140$ mesh.: There were two low effluent automatic shut-downs during the run, both caused by rough operation of the system pressure control valve (effluent valve). This problem was probably caused by icing in the valve body.. 'l'he run was finally terminated because of the coal feeding problems.

For $\mathrm{HC}-11$ remaining feed coal was resieved to remove the excess fines. Run HC-ll went very smoothly for two hours. Then the run was terminated because of difficulties in maintaining adequate $\mathrm{H}_{2}$ and $\mathrm{N}_{2}$ supply pressures. - During the two hours of operation, coal was fed at $10.0 \mathrm{lb} / \mathrm{hr}$, and the steady state reactor bed temperature was: $1050^{\circ} \mathrm{F}$. Because of the short duration of coal feed, no data analyses are presented for: this run.

Work Forecast. Routine experimentation will continue in February with a recirculating fluidized-bed run $\mathrm{HC}-12$ at $300 \mathrm{psig}$ and approximately $1050^{\circ} \mathrm{F}$.

\subsection{Residue Carbonization}

F. H. Wilson, J. B. Gibson, L. S. Dickerson, and R. L. Andrews

This project for supporting research and development on residue carbonization is supported by the Division of Coal Conversion and Utilization of ERDA. The work in the year beginning November 1, 1975, consists of three tasks: (1) a review and evaluation of experience with the low temperature carbonizer in the Cresap. W. Va., pilot plant, (2). modification of an existing reactor to permit continuous feed of solidsladen residues, and (3) operation of the reactor with three feedstocks (vacuum distillation bottoms from the $\mathrm{H}$-Coal process and solvent extraction underflows from SRC and CSF product liquids) at three temperatures up to $1200^{\circ} \mathrm{F}$.

\section{Summary}

During the month of January 1977, three runs were made in the residue carbonization reactor. The first two were made with Illinois No. 6 coal and the third was made with char from the Hydrocarbonization experiment. Some old equipment was cleared from the laboratory and some new equipment was fabricated to be installed. Three sets of analytical data were received.

\section{Work Accomplished}

Two carbonization runs were made with $\sim 40$ mesh Illinois No. 6 coal in order to determine its agglomerating properties. The first run, ICC-I, was started with a bed of about 1000 grams of char, a reactor temperature of $1120^{\circ} \mathrm{F}$, argon flow rates of .11.1 SLPM to the draft tube and 17.2 SLPM to the downcomer, and a feed rate of about $2 \mathrm{lb} / \mathrm{hr}$. Feed was. maintained for 22 min at which time we got a high pressure alarm and shut down. During clean-up of ICC-I a plug of brittle, fluffy, gray solid was found 
which had completely filled the space in the reactor between the top of the draft tube and the deflector cup, as well as filling the full length of the 24 in. draft tube itself. A second run, ICC-2, was made with all conditions the same as in ICC-1 except that a starter bed of 2000 grams of char was used. This run lasted for $13 \mathrm{~min}$ before a high pressure alarm occurred. The reactor had been plugged with agglomerated solids, not as fluffy as those in ICC-l, again filling the full length of the draft tube, but this time forming a plug around the draft tube in the downcomer region. We have concluded from these two runs that Illinois No. 6 agglomerates in a $4 \mathrm{in}$. diameter draft tube reactor like the one used in these runs.

The third run was made with char from the Hydrocarbonization experiment in order to drive of $f$ any volatile materials left in the char due to insufficient temperatures in the Hydrocarbonization runs. This devolatized char will be mixed with residue for use in future Residue Carbonization runs. After sieving the char to $\sim 50$ mesh size, 64 lbs of it was fed into the reactor at a temperature of $1100^{\circ} \mathrm{F}$ over a period of 6.0 hrs. After the run, 52.3 lbs of char was left in the reactor and the char receiver, and 4.9 Ibs of fines had blown over to the scrubber, for a total of 57.2 lbs of devolatilized char. Tars collected in the scrubber and the string filter amounted to 0.6 lbs. Samples of the char were taken before and after devolatilization for ultimate and proximate analysis. Except for a few initial difficulties due to feed holding up in the feed tube, the char devolatilization run was trouble-free.

Several alterations of the Residue Carbonization set-up are underway. Hydrogen gas supply equipment t'rom earlier hydrocarbonization experiments, being of no further use, was removed to make more working space in the lab. A cold trap has been fabricated and will be installed between the scrubber tank and the string filter. This cold trap will use Dowtherm $J$ and a copper coil in dry ice to condense organic liquids which escape from the scrubber. When methyl napthalene was used as a scrubber liquid these vapors condensed in the off-gas lines fouling the solenoid valves.

Three analytical reports were received this month. The first, shown in Table 2.4, shows the ultimate and proximate analysis of samples taken during clean-up of runs $R \mathrm{R}-\perp \bar{y}$ and $R \bar{C}-20$. T'able 2.5 shows the results of a mass spectrometer analysis of off-gas samples taken during run RC-2l. This run was frequently interrupted by plugging in the feed line, as reflected in the "time elapsed since most recent feed restart." Finally, Tables 2.6 and 2.7 show an assessment of PAH present in H-Coal Vacuum Tower Bottoms, sampled from our supply of residue, which was a result of a study done by another program at ORNL, at no cost to our program.

\section{Work Forecast}

Alterations in the system will be carried out including installation of the new cold trap, shortening of the line from the reactor to the scrubber; installation of a controlled heater for this line, reorganization of the pressure monitoring system and further maintenance as 
Tajle 2.4. Ultimate and proximate analysis, RC-19 and RC-20

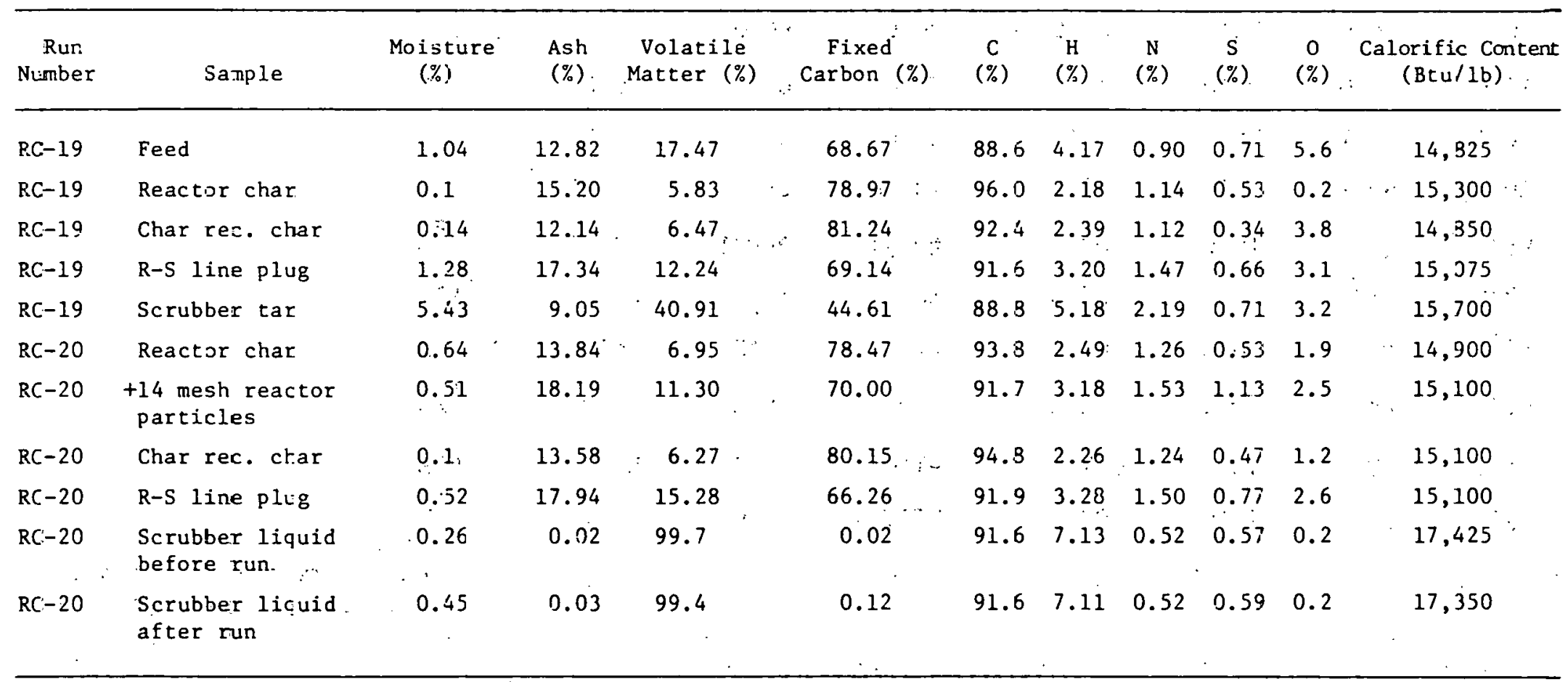


Table 2.5. Mass spec. analysis of off-gas, RC-2l

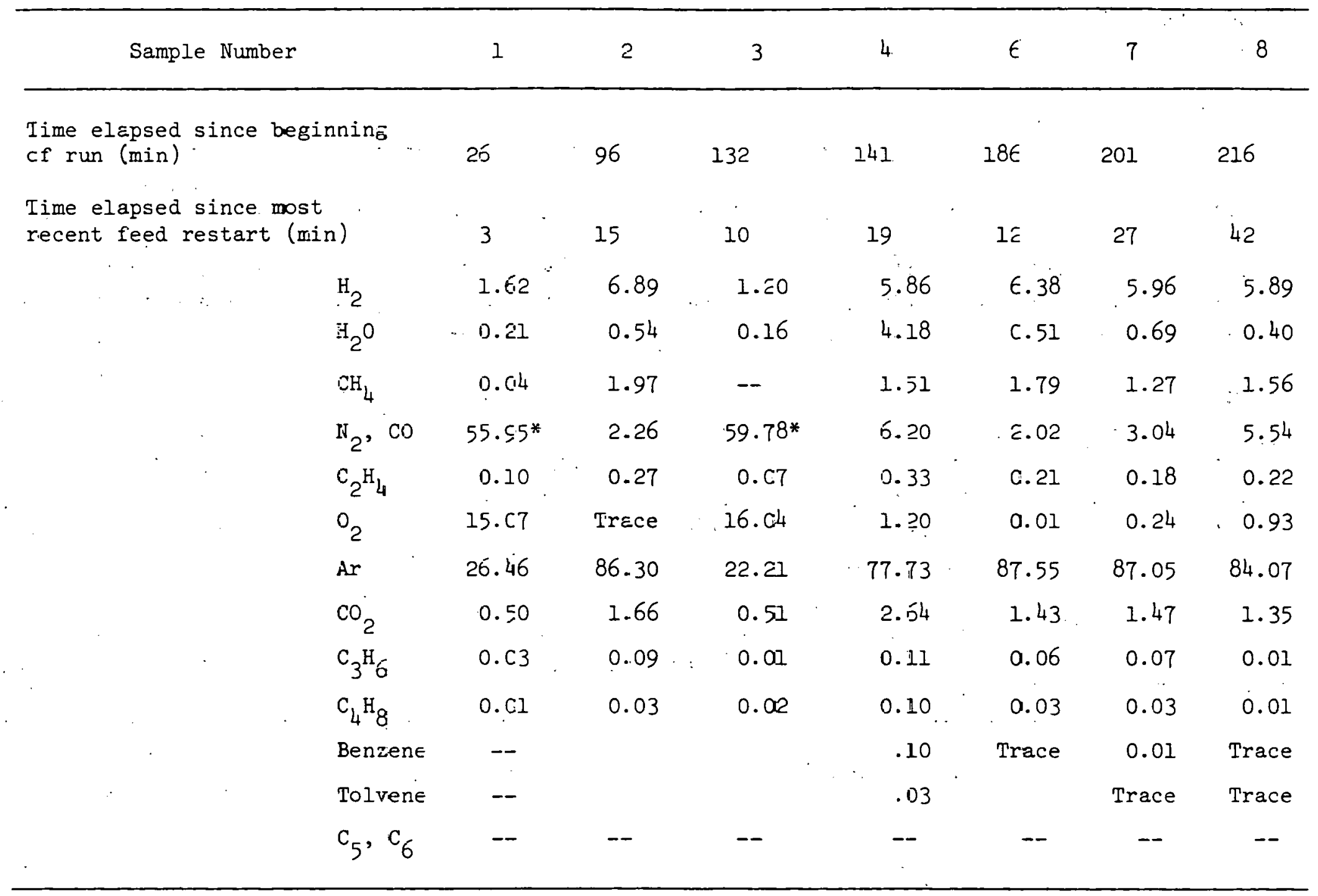

NOTE: Sample No. 5 was lost because of tad seal

* Extra air in sample 


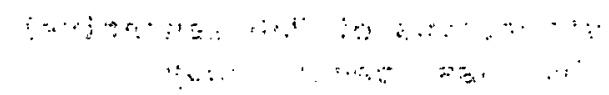

Table 2.6. Quantitate determination of PAH identified in H-Coal VTB by cochromatography and mass spectroscopy

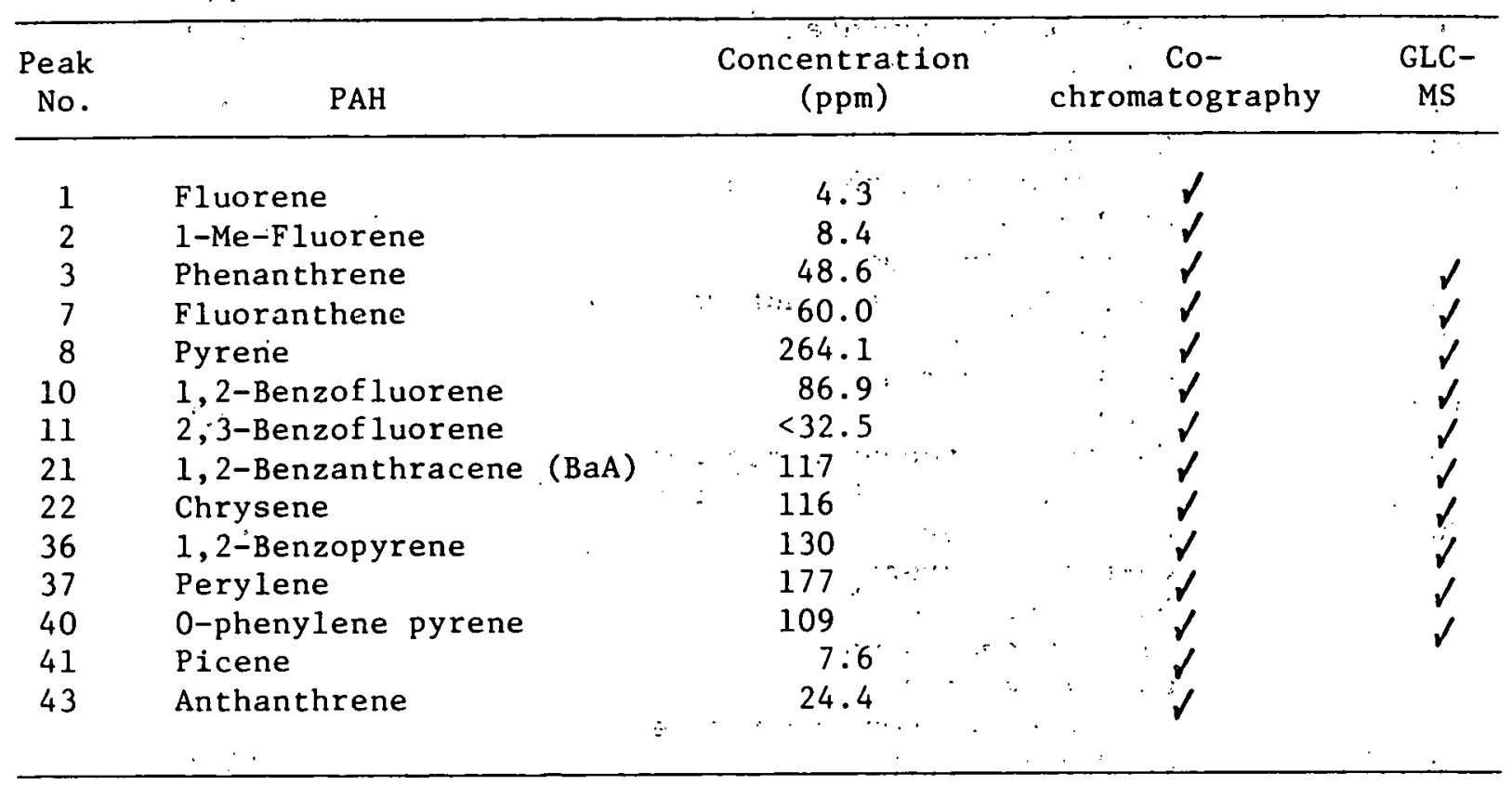


Table 2.7. Semi-quantitative estimations of PAH tentatively identified in H-Coal VTB by mass spectroscopy

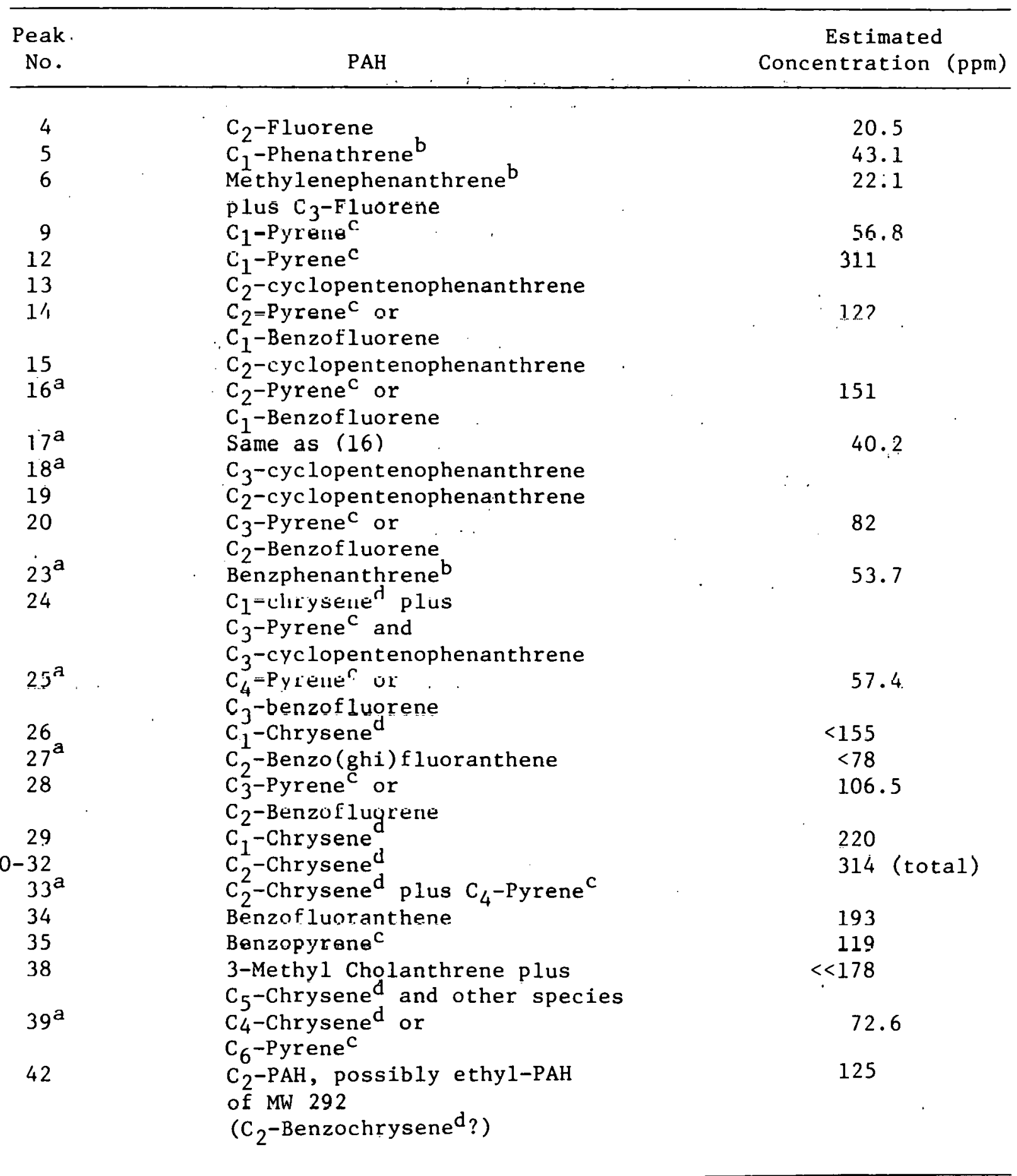

${ }^{a}$ Mass Spectrum suggests several PAH are present.

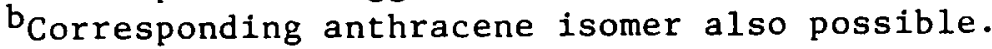

c Corresponding fluoranthene isomer also possible.

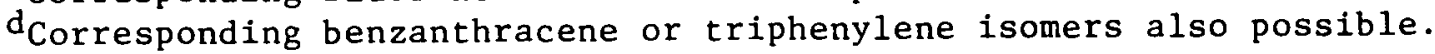


required, A Residue Carbonization run, using a 4/1 char to residue feed, will be made to check out these improvements on the system.

2.3 Experimental Engineering Support of an In Situ Gasification Process

R. C. Forrester III, G. D. Owen, and S. M. Gibson

Samples of Eastern bituminous coal have been obtained from the Morgantown Energy Research Center (MERC) for use in our large-block pyrolysis studies. The coal is typical of the material which will be burned by MERC in their field test near Pricetown, West Virginia, later this year.

The coal was machined into $15-\mathrm{cm}$ right circular cylinders, then drilled to accept $1.2-\mathrm{mm}$ thermocouples for internal temperature measurement. The first specimen was heated to $1000^{\circ} \mathrm{C}$ at $0.3 \mathrm{c} \% \mathrm{~min}$.

Although the analysis of evolved oil and gases is not yet complete for this test, several interesting observations were made during the pyrolysis. Gas evolution was quite erratic, not following the smooth production curves observed with Western,subbituminous coals. Furthermore, at the conclusion of the experiment, the car showed no pyrophoricity whatsoever. From the appearance of the char in the reactor, it was clear that the specimen had undergone significant swelling and/or plastic flow within the confines of the reactor. The surface of the char was also shiny (almost glass-like) in stark contrast to the dull, porous appearance of chars produced by pyrolysis of subbituminous coals.

Further tests at different heating rates and to lower temperatures are planned.

\subsection{Coal-Solvent-Hydrogen Mixing}

J. R. Hightower, Jr., R. C. Lovelace,

J. M. Begovich, and S. M. Gibson

Studies of liquid mixing in coal-solvent hydrogenation reactors have continued. During the past month a series of residence-time, liquid hold-up, and pressure drop measurements has been completed for air and clear water flowing cocurrently upward through a bed packed with 4-mmdiam glass spheres, and a Kenics in-line static mixer has been ordered for testing as an alternate reactor.

A series of 115 runs has been made in which axial dispersion, liquid hold-up, and pressure drop have been measured in a 1-in.-diam by 10-ftlong column packed with 4-mm-diam glass beads. The first 22 runs were done to perfect the pulse-test technique. Gas flow rates were 0-287 
$\mathrm{cm}^{3} / \mathrm{sec}$ (at the column pressure and temperature) and liquid flow rates were 0.99 to $3.94 \mathrm{~cm} / \mathrm{sec}$. These flow rates encompass the liquid and gas volumetric flow rates $(1.05 \mathrm{~cm} 3 / \mathrm{sec}$ slurry and $80 \mathrm{~cm} 3 / \mathrm{sec}$ at 4000 psi and $\left.450^{\circ} \mathrm{C}\right)$ used in the l.l-in. Synthoil development reactor operating at the Pittsburgh Energy Research Center (PERC). Calculations which extract dispersion coefficients and liquid hold-up from concentration pulse recordings are now under way. Preparations are now being made to circulate a coal-water slurry through the column and to make a similar series of measurements with slurry and air flowing through the column.

A Kenics in-line static mixer will be tested in the l-in.-diam column when tests with packed column have been concluded. This device is a series of fixed right hand and left hand helical elements which are enclosed in a tubular housing. For fluids in turbulent flow this. geometry causes complete stream inversion, creates microscale turbulence, and produces radial mixing. For coal conversion applications its low restriction of cross sectional area is conducive to low erosion rates and plug-free operation. Six mixing elements have been ordered. These will allow a 5-ft-long contactor which will hold the mixing elements to be fabricated.

\subsection{Pressurized Carbonization of Residue}

R. E. Barker, S. M. Gibson, and J. R. Hightower

During January fabrication and installation of the experimental apparatus has proceeded. The four main vessels, preheater, carbonizer, feed tank, and condensate receiver have been installed, along with the connecting tubing. The instrumentation has been calibrated and is bejing installed. Pressure vessel review has been satisfactorily completed, and the vessels have passed hydrostatic testing.

Installation of equipment and instrumentation will be complete by mid-February with a pressure test at operating conditions and shakedown runs later in the month. The first residue carbonization experiment may be attempted in late February. 


\section{MATERIALS -ENGINEERING}

R. T. King

The materials engineering and associated technology reported here are in support of activities directed by the Materials and Power Generation Branch of the Division of Materials and Exploratory Research. Other related work not funded directly by this division of ERDA/FE is included also.

\section{$\underline{\text { Summary }}$}

The piping and pressure vessel program has experimental work in progress to determine the effects of heat treatment on thick $21 / 4 \mathrm{Cr}-1$ Mo plate.

A FY 1977 Work Statement for inspection techniques for wear- and process-resistant coatings was completed. We are assembling a comprehensive technical report on plasma-sprayed coating inspection. We are ready to install our new $x$-ray fluorescence measuring system; delivery has been delayed by minor equipment problems and the gas shortage. Thermal experiments with ceramic coatings have not been successful. Eddy current work is progressing satisfactorily. Modifications to our high voltage probe recording system are still in progress.

Experimental deposition of Alloy $20^{\circ}$ cladding on carbon and low-alloy steels, and testing for cracking and microfissuring is in progress.

During this reporting period an eddy current inspection system has been designed and fabricated and will be used for the inspection of the surveillance test tubes previously subjected to a 500 hour exposure in a fluidized bed coal combustor environment.

\subsection{Pressure Vessel and Piping and Technology Assessment}

D. A. Canonico

Simulation of the microstructures at the surface and quarter thickness locations of thick $21 / 4 \mathrm{Cr}-1$ Mo plate is being done through the use of the DATA TRAK. Various austenitizing temperatures and cooling rates after austenitizing are being investigated. Mechanical testing is proceeding and tensile properties are currently being obtained.

- A draft of the report, Assessment of Materials Technology of Pressure Vessels and Piping for Coal Conversion (ORNL-5238), has been completed. Fifteen (15) copies were delivered to Fossil Energy Research early in December. 


\title{
3.2 Inspection Techniques for Wear- and Process-Resistant Coatings
}

\author{
R. W. McClung and G. W. Scott
}

\subsubsection{Review and Evaluation (G. W. Scott)}

A draft quarterly report for the period October-December 1976 has been proposed and submitted to our technical publications group for editing and reproduction. A draft work statement for FY 1977 was prepared and sent to ERDA/FE on January 20. We are assembling a comprehensive report covering the first year's work at ORNL on coatings inspection. 'l'his report will be limited to plasma-sprayed coatings; it will include a technical assessment of the total inspection problem and a review of accomplishments from this laboratory.

A modest literature review of diffusion-bonded and alonized coatings has begun. We have contacted the Alon Processing Corporation t'or additional information on their coatings.

\subsubsection{Penetrating Radiation (G. W. Scott)}

We have completed preparations for the installation of our new $x$-ray fluorescence measuring system. Two. NDT-Group representatives visited the Seller on January 17 to witness a demonstration of the system. The system was complete and acceptable except for some loss of resolution in one range. The seller agreed to upgrade the system as required; however, he has been forced to shut down temporarily because of a natural gas shortage. The delivery date is uncertain at this time.

\subsubsection{Thermal Testing (W. A. Simpson, Jr.)}

We have examined a number of in-house high temperature heat injection devices for possible use as heat sources in the experimental portion of our thermal studies on ceramic coatings. The sources ranged f'rom a simple natural gas-air torch to a plasma arc device. The latter appeared to be most suitable in terms of heat injection rate but would be fairly difficult to incorporate into a test system because of its physical configuration. Consequently, we are continuing to depend heavily on our induction source as the primary means of heat injection. We will continue to consider the hot gas sources, however.

We continued to inspect our one non-bond standard using induction heating. Repeated efforts to detect the flaw have thus far not been successful. These results suggest that either we are relatively far removed from an optimum test configuration or the standard does not in fact contain an unbond. The latter possibility is being examined via alternate nondestructive tests; however, these tests should be inherently less sensitive than thermal techniques to unbonding in these samples. 


\title{
3.2.4 Eddy Currents (C. V. Dodd)
}

We are still: working on the self-calibration feature for the liftoffconductivity instrument. A two-frequency instrument is being assembled for use on metallic and cermet coatings.

\subsubsection{High Vंoitage Probe (G: W. Scot}

We are assembling and testing our plan view recording system. Some components are in place and connected; some electronics is still in the fabrication shop.

\subsection{Iron and Nickel Carbonyl Formation and Prevention}

\author{
J. H. DeVan, H. Inouye, and J. Brynestad \\ Program terminated December 31, 1976.
}

3.4 Development of Techniques for Welding and Cladding $\mathrm{Cr}-\mathrm{Mo}$ and Low-Alloy Steels

G. M. Best, D. P. Edmonds, and G. M. Goodwin

We are continuing to investigate methods for producing sound clad layers of Alloy 20 stainless steel on carbon and low-alloy steel substrates for coal conversion applications. A literature review of cladding techniques for these materials and problems with them is presently being prepared. Our development program is emphasizing gas metal-arc (GMA) and submerged-arc (SA) cladding of Alloy 20 (type 320 stainless steel). Different welding conditions were used to make SA type 320 deposits on carbon steel substrates, with 20 and $35 \%$ dilution. The deposit with $35 \%$ dilution showed gross microtissuring and hot cracking, while the $20 \%$ dilution deposit showed only minimal microfissuring using optical metallography. We are performing side-bend and face-bend tests on these deposits so that microfissures can be more easily detected. In addition, we are preparing to make oscillating GMA clad deposits using techniques to minimize dilution.

\subsection{Prestressed Concrete Pressure Vessel Studies}

W. L. Greenstreet

All studies have been completed. The draft report is in preparation. 


\subsection{Fluidized Bed Combustion}

C. V. Dodd, R. H. Cooper, and J. H. DeVan

This eddy current system measures magnitude and phase at two different frequencies and has been coupled to a single board microcomputer (the NDT-COMP 8) to control the experiment and reduce the data. At this time, a calibration program has been written to make 8 readings of magnitude and phase at each frequency, average the results, and print them out on a terminal.

This system will be used to measure tube wall thickness to within $0.2 \mathrm{mils}$, resistivity of tube material to within $0.3 \mu$ or $\mathrm{cm}$, and the coil to conductor spacing to within $0.030 \mathrm{in}$.

A set of calibration standards has been machined with different wall thicknesses $(0.036,0.041,0.048$, and $0.068 \mathrm{in.})$ and of different materials ( 304 stainless steel, I800, I600, and 310 stainless steel). Experimental measurements are being made on these samples to make fine adjustments in the instrument calibration and verify the other computer calculations. The coefficient and equations for calculating the properties will be programmed into the microcomputer when they are verified. A self calibration program will also be incorporated into the instrument. 


\section{ALKALI METAL VAPOR TOPPING CYCLES}

R. S. Holcomb and G. Samuels

\subsection{Potassium Vapor Topping Cycle}

R. S. Holcomb, D: B. Lloyd, and R. H. Guymon

\subsubsection{Contract Objective}

Design, construction," and testing of a" full-scale potassium boiler tube bundle and burner module on water and then potassium to determine the performance and operating characteristics.

\subsubsection{Status Summary}

1. The vapor separator assembly for the water test was installed in the boller drum.

2. The supply of natural gas to the experiment was terminated on January 20 because of a forced reduction brought about by the unusually cold weather. Arrangements are being made to install a propane supply system to provide fuel throughout the rest of the program. This has caused a delay in completion of the water test, but construction work on the tower will proceed during the period required to install the propane system.

3. The structural drawings for the tower extension were completed and transmitted to the CPFF contractor.

4. Design work completed this month includes one drawing for the condensate return piping, nine electrical drawings, and two instrument and control drawings.

5. Fabrication work completed includes welding the argon separator to the condenser piping, installation of twelve condensate lines and thirty thermocouples, welding on one head of the drain tank, and wiring of electrical and instrument cabinets.

6. Plans for Next Month. Construction on the tower and installation of potassium components will be initiated; the propane supply system installation will begin and may be completed during the month; design work will continue on the air and argon piping, electrical and instruments and controls; fabrication of the drain tank and sample box will be completed. 


\title{
4.2 Coal-Fired Alkali Metal
}

\author{
G. Samue1s
}

\subsubsection{Contract Objective}

The objective of the Coal-Fired Alkali Metal Power System Design Study is to establish a reference design for a 200-MW(e) alkali metal vapor/steam Rankine cycle system employing a coal-fired fluidized bed furnace and to prepare a detailed preliminary design of a fluidized bed furnace. This will be accomplished by preparing designs for both potassium and cesium vapor cycle systems and making a comparison of these designs. The results will be analyzed and potassium or cesium will be chosen as the cycle fluid and one of the designs will be selected as the reference system. The reference system will be used for the preparation of a detailed preliminary design of a fluidized bed furnace-boiler.

The program will consist of two phases. The first phase will compare several systems using both potassium and cesium as the working fluid. The scope of work for this phase of the program will include the following major casks:

(1) Parametric cycle analyses for cesium and potassium power systems.

(2) Furnace-boiler conceptual designs for furnace pressure of 1 to $10 \mathrm{~atm}$.

(3) Condenser-steam generator conceptual designs for cesium and potasslum ati several condenser cemperatures.

(4) Metal vapor turbine design and analysis.

(5) Survey of cesium availability and cost.

(6) Conceptual designs and layouts of selected systems.

The results of these tasks will provide a variety of conceptual designs for both cesium and potassium. A detailed comparison will be made of the relative merits of the various concepts from which a reference design using either potassium or cesium will be selected. This system will be used to prepare a detailed preliminary design of a fluidized bed furnace-boiler. 


\subsubsection{Status Summary}

1. The first phase of the cycle analysis has been completed. This was a parametric analysis of the three basic systems of the plant. This analysis gave a total of 972 combinations of which 810 influence the plant efficiency and 162 influence component heat: loads and design conditions.

2. The first phase of the metal vapor turbine design and analysis has been completed... This effort: was restricted: to: a determination of the number of stages; hub: diameter, blade height and stress, and turbine efficiency.

3. Work on the fluidized bed furnace-alkali metal boiler for the intermediate and high pressure combustion air systems was continued.

4. Work on the alkali metal condenser-steam boiler was started. The initial effort is directed toward units using reentry type tubes.

$\therefore \quad \cdots \quad \because$

5.. A revised program plan and a system definition was prepared.

6. A meeting was held with ERDA-FE personnel in Washingt on on January 11,1977 , to reach agreement on reporting procedures and future plans: for : the program. 
5. CRITICAL COMPONENTS TEST FACILITY

\section{R. E. MacPherson}

A first draft of the report on the preliminary conceptual design study of the component test modules has been prepared and is ready for internal review. The test modules being addressed in the report. include those for testing lock hopper valves, slurry pumps, continuous dry coal feeders, and hot gas cleanup systems. Although ERDA-FE has interest in other test capabilities such as for compressors, power recovery turbines, and coal beneficiation equipment, limited funds and a specified study completion date of January 31,1977 , made it advisable to postpone consideration of these 1tems to à later date.

The Stearns-Roger, Inc., work on their subcontract to supply assistance tor this study was reviewed in their Denver, Colorado, office on January 18 , 1977. At that time their work was complete as scheduled. Their design recommendations and cost estimates are included in the report draft of the preliminary conceptual design study.

ERDA-FE has recently requested an independent contractor to conduct a survey to determine industrial reactions to the concept of testing demonstration plant critical components in government sponsored test facilities. We will not proceed further until the results of this survey are available. 
6. ENGINEERING STUDIES AND TECHNICAL SUPPORT

J. R. McWherter

6.1 Process Modeling Support

R. Salmon, D. 'S.' Joy, and D. Lister

Contract Objective. To assist Purdue and Lehigh Universities in the * development of computer programs for the simulation of coal-conversion plants.

\section{Status Summary}

1. Progress on the project was reviewed with representatives of Edgewood Arsenal at a meeting at Oak Ridge National Laboratory on January 13, 1977.

2. Work continued on the development of computer programs for cost estimation and economic evaluation. "A report describing the computer program PRP (calculation of production cost) was completed and is in the process of being issued. The PRP program is completed and is in use. A program for calculation of piping system layouts and costs is in work. The plotting program for the system layout is essentially finished. Example layouts from this program were shown at the meeting referred to above. Cost data for use in the program are being developed through contacts with industry.

Changes. None

Problem Areas. Acquisition of process data on the ICGG gasification system remains a problem. The data are needed by Purdue and lehigh in connection with the development of their simulation models, which are to be based on the ICGG flowsheet.

Open Items. None

Supporting Data. See Problem Areas.

\subsection{Procese Research Digest \\ F., J.: Endelman and S. P. Singh}

-The first draft* of the article on the Mobil Research and Development Corporation project for converting methanol to gasoline and the first draft of the entire article on the Flash Hydropyrolysis of Coal Projects were completed and submitted to the Technical Editor of the Digest for review and comments.

* The services of a technical writer, F. M. O'Hara, were used in preparing this draft. 


\subsection{Survey of Industrial Cual Conversion Equipment Capabilities}

J. M. Holmes

\subsubsection{Rotating Components (W. F. Boudreau, J. R. Horton, M. Siman-Tov, and W. R. Williams )}

\section{Objective}

The objective of this survey, which is being conducted for the Major Facilities Project Management Division (MFPM) of ERDA/Fossil Energy, is twofold:

1. to determine the present capability of the United States' industry to supply the equipment needed for future demonstration and commercial coal conversion plants; and

2. to determine research and development needs, including lead time requirements, for producing equipment of advanced design.

This report deals with rotating components (compressors, pumps, turbines and expanders), one of four items covered by this survey.

Status

During the month of January, preliminary equipment lists were compiled from three additional conceptual designs of commercial coal conversion plants. The seven designs presently forming a basis for this study are listed in Table 6.1. Final equipment lists should be ready for industry appraisal and comment by mid-February.

A letter was prepared for the Commerce Business Daily (CBD) to obtain an indication of industry readiness to supply information on their present capabilities for design and manufacture of rotating equipment for coal conversion facilities, as well as comment on research and development needs. The letter was issued through T. K. Lau from the office of MFPM in ERDA/FE and appeared in the January 28 issue of CBD.

On January 27 and 28, T. K. Lau and J. L. Powell visited ORNL to review the status of this project and other related studies. A viewgraph presentation was made on January 27 of the present status and of the schedule and future plans for the project in a meeting covering all four items included in this survey. Individual meetings were conducted the next day. At this latter meeting it was determined that processes for direct combustion of coal, including fluid bed combustion, would not be specifically considered during this study. (Direct combustion processes were mentioned in the CBD letter in order to leave the options open.) Also, gas turbine requirements will not be dealt with in depth since a detailed study of turbine technology is being conducted by the Coal Conversion and Utilization Division of ERDA/FE. 
Table 6.1. Conceptual Designs Analyzed for Equipment Requirements

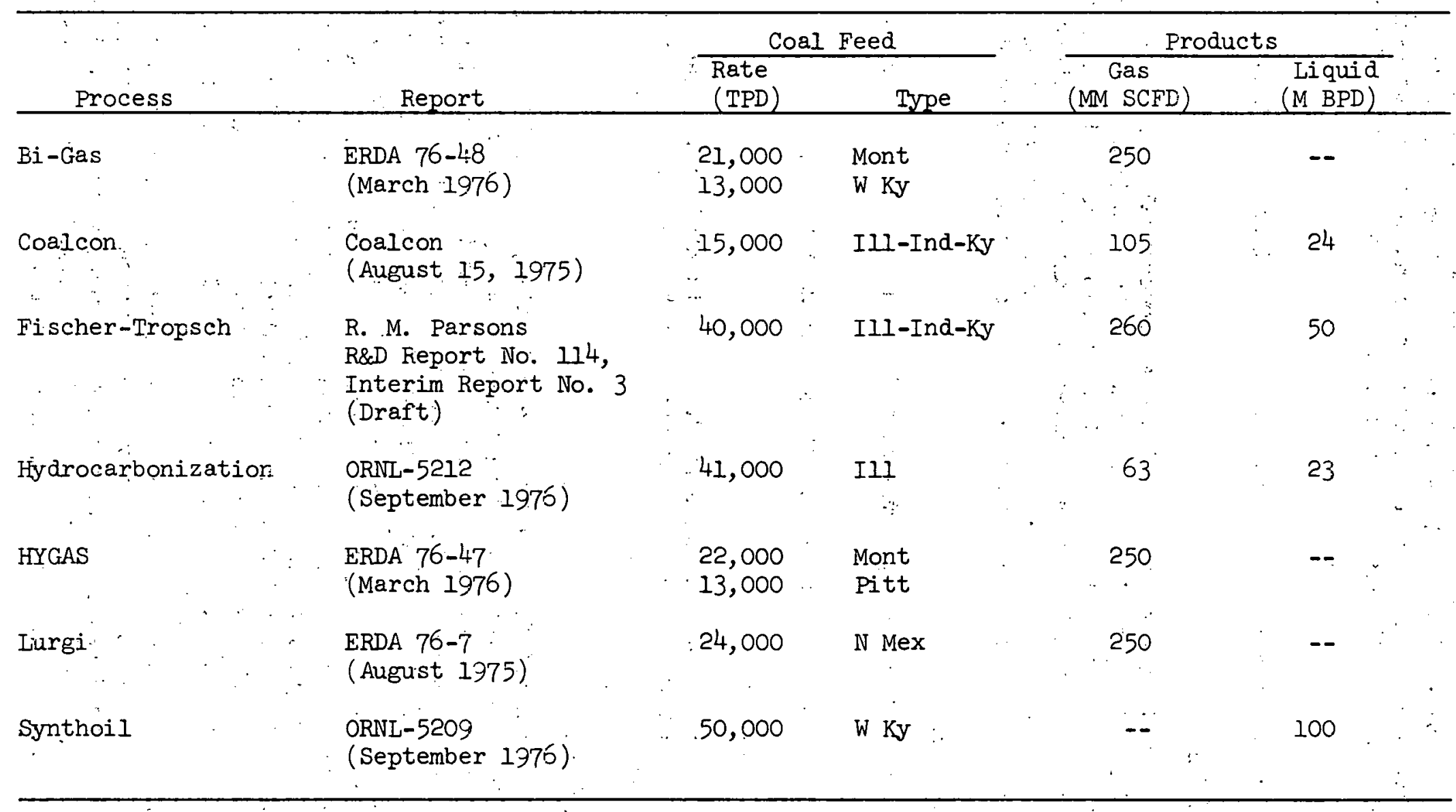


A list of manufacturers supplying rotating equipment has been prepared. Final equipment lists and questionnaires on industry capabilities and R\&D needs will be sent to selected manufacturers as well as to those responding to the CBD letter during the latter part of February.

\section{Changes}

No changes have been made in established plans (see Problem Areas). $\underline{\text { Problem Areas }}$

As a result of adding the additional conceptual designs to the study and some delay in approving the issuance of the CBD letter (planned for mid-January), the project is approximately two weeks behind schedule. Manpower requirements have been greater than anticipated. These problems are not expected to cause great difficulty and should not affect projected dates of completion of the survey, analysis or report phases of the project.

\section{Supporting Data}

Table 1: Conceptual Designs Analyzed for Equipment Requirements

6.3.2 Valves (W. A. Bush, E. C. Slade, and Joel Wisner)

Contract Objective

The objective of the valve study is to identify the capability of industry to supply critical valves that may be used in coal conversion processes.

Slatus Summary

Four processes' flow sheets were evaluated, (Hygas, Bigas, Snythoil, and Coalcon), and streams are being classified by pressure, temperature and corrosive characteristics in order to determine their valve requirements. Values have been assigned and are being tabulated in order to show possible problem systems as opposed to systems which can be classified as conventional (e.g.,, 900 Ib Ansi. carbon stl. to code B31.1). The conventional systems will then be discounted and attention focused upon the "peculiar" systems. Other processes as we $\perp$ as the tour mentioned above were also studied for guidance. The corrosive effects of the systems are being evaluated using the tabulations obtained above from the process flow sheets. Several mediums have so far been related to different materials (e.g., Hydrogen gas to ASTM-Al82-F316 pipe).

Guidance hàs been found and àdväntage hás and will be taken of previous "parallel" type studies such as Advanced Energy Systems - New Fuels - Stanford Research Institute 1974. Further assistance is expected through N:T.I..S. (see literature search). N.T.I.S. "Energy" abstracts are being reviewed for possible "project" applications. 
A preliminary investigation was made of the materials for valves. Part of the investigation was on the carbon content: and the possible addition of other elements to austenitic steels.

Considerable information has been acquired pertaining to advanced coal slurry injection design and is being evaluated for application.

An N.T.I.S. search has been performed and some pertinent data has been retrieved. The results of the search are still being evaluated. However, the search when "keywording" to "coal conversion" - "valves", produced a zero. Better input and further understanding of keywords systems, components, piping is expected to produce improved results.

Contact was made with other people who are pursuing similar lines of investigation or who may have had parallel experience. Efforts are being made to avoid duplication of work and to take maximum advantage of existing information.

A catalog library was started using literature from probable suppliers and will be maintained and updated. A list of manufacturers was compiled.

Meetings were held with the ERDA Project Manager to discuss the status, progress, and direction of the project on January 27 and 28.

6.3.3 Hot Gas Cleanup Devices (M. S. Edwards, J. P. Meyer)

1. Contract Objective

Conduct surveys of industrial equipment capabilities that will identify the present capability of industry to supply hot gas cleanup devices.

2. Status Summary

a. The literature search on previous studies and survey reports is complete. Further effort is underway to. identify possible information available from allied industries (e.g., refineries, coking plants).

b. A preliminary list of equipment vendors and developers was compiled. General engineering firms and other organizations who may have experience in the area of hot gas cleanup are also being identified. This list. was given to the ERDA program manager.

c. Preliminary drafts of letters to be sent to vendors and general information sources were prepared. These were presented to the ERDA program manager for comment and approval.

d. A meeting with program manager T. K. Lau and J. Powell of the Major Facilities Program Management Division of ERDA/FE was held on January 27, 1977 to review the overall program. A second 


\begin{abstract}
meeting with 'Il: K: Lau was also held on January 28, 1977 to review only the section on hot gas cleanup devices.

e. The next task within the survey of hot gas cleanup devices will start in February with contacting the identified equipment vendors and developers. An effort will also be made to obtain further information from general contractors and others knowledgeable in the field of hot gas cleanup.
\end{abstract}

\title{
3. Changes
}

Jim P. Meyer has been added to the ORNL effort on hot gas cleanup surveys. He will have prime responsibility for contacting vendors and general int'ormation sources.

4. Problem Areas

No problem areas encountered to date.

5. Open Items

Nurie

\section{Supporting Data}

None

\subsubsection{Heat Recovery Equipment Survey (W. R. Gambill)}

Contract Objective

The objective of this survey is to evaluate equipment potentially suitable for the recovery and utilization of heat in process streams (gas, liquid, solid, and mixed phase) from primary exothermic coalconversion process steps. Such process steps may include direct hydrogasification, solution hydrocracking, shift conversion, methanation, methanol synthesis, and Fischer-Tropsch synthesis. Extraction of heat from primary process steps will not be included since this area is quite different regarding both goals and criteria. The approximate range of hot-stream temperatures will be $300-2700^{\circ} \mathrm{F}$. Information will be collected. and evaluated regarding descriptions, sizes, costs, and commercial applicability of regenerators, fluid bed contactors, heat pipes, related equipment, and, to a limited degree, conventional heat exchangers.

\section{Status Summary}

A literature survey of equipment types, including.regenerators, heat pipes, and augmented recuperators, was continued. A report prepared by Fluor for EPRI (AF-199, July 1976) indicates that overall heat-transfer coefficients for coal liquefaction plant heat exchangers have varied over the following typical ranges: 


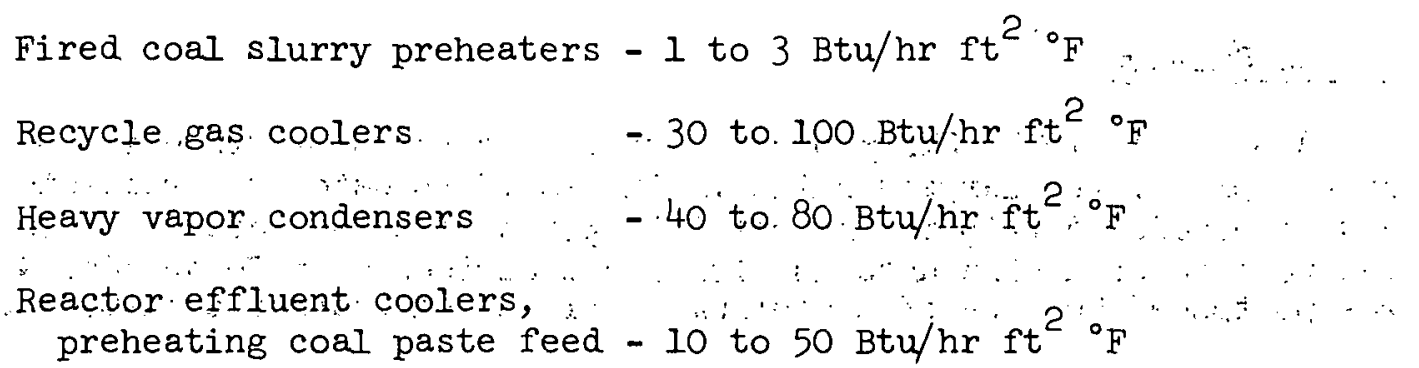

A dozen papers presented at the Fifth International Heat Transfer Conference (Tokyo, September 1974) have been:identified as being potentially germane.

The Reynolds moduli for liquid or slurry streams in coal liquefaction pilot plant heat exchangers (Bergius, SRC, and CSF) were estimated from available data. Except for the Cresap (CSF) fired preheaters, for which the $\mathbb{N}_{R e}$ was apparently $\sim 10,000$ to 15,000, the moduli varied from 6 to 1600, indicating stable laminar flow.

Reports were obtained from Prof. A. E. Bergles of Iowa State University describing their studies of laminar-flow heat transfer augmentation by means of internally finned tubing and various inserts twisted tapes and Kenics and Koch static mixers. The results seem sufficiently promising (film coefficients doubled to tripled) to justify discussions with Heat Transfer Research, Inc. (HTRI) in Alhambra, California. HTRI is extending the small diameter, constant wall heat flux studies conducted at Iowa State to larger diameters with a constant wall temperature, using very viscous fluids. HTRI should also be able to suggest contacts with all major U.S. heat exchanger vendors. A trip is planned for February.

Meetings were held in Oak Ridge on January 27-28 with J. Powell and T. K. Lau to discuss this and other surveys relating to industrial coal conversion equipment capabilities.

\subsection{Large Air Separation Plant Study}

\section{Contract Objective}

The primary objectives of this study are to determine if significant economies of scale would be provided by building single-train cryogenic air separation plants with capacities in the range of 2000 to 20,000 TPD oxygen production. The oxygen purity is to be $95 \%$ or higher; and the delivery pressure, within the range $I$ to $70 \mathrm{~atm}$. abs., is to be determined by economics. 


\section{Status Summary}

A December 1976 ASME' papër describing features of Linde's 2000 TPD oxygen plant, the largest built in the world to date, was requested and received. A trip to inspect this plant, located outside of Chicago, and to discuss design details with Linde engineers in Tonawanda, N. Y., was postponed because of a meeting conflict and weather conditions.

A suggested letter of inquiry for the oxygen plant study and a list of vendors was sent to UCND Purchasing, which has since transmitted the material to the Contract Division of ERDA/ORO. 
7. PROCESS AND PROGRAM ANALYSIS

J. R. McWherter and R. Salmon

Process and program analysis studies are being conducted for the ERDA Fossil Energy Office of Program Planning and Analysis. This effort includes research studies on most of the coal conversion and utilization processes. The program objective is to provide, on a consistent basis, technical and economic evaluations of competing processes and systems for coal conversion and utilization.

A preliminary draft of a proposed common economic basis for use in the evaluations was completed. Copies were given to ERDA/FE/OPPA and Ralph M. Parsons : Company for their comments. "After comments have been received, it is planned to issue a final version in report form.

\subsection{Low Btu Gasification}

J. P. Belk; H. F. Hartman, and D. E. Reagan.

Activities in January 1977 involved the process screening/selection method, the acquisition of data for gasifier processes: and a review of economic considerations.

\section{Process Screening/Selection}

Work continued on the development of the screening method which. will be used to reduce the number of processes evaluated in depth to about 20 . Criteria being used in the method include:

(1) degree of commercialization considering present status, level/ source of funding and projected timing

(2) technical aspects such as gasifier complexity, feed require'ments and uperatins cunditiuns.

(3) capacity factors including coal throughput, gas heating value, and "production rate".

(4) information availability which considers the type, amount, and depth of the studies, reports and proposals .

Selection and scheduling of processes to be evaluated in depth are being done by using the folluwing inforination.

(I) data: accumulated in preparing short summaries of each process in the initial survey

(2) the screening method and the above criteria 
(3) a generic comparison of processes by gasifier type (rixed bed, fluid bed, entrained flow, molten bath)

Work to date has identified the first three processes for inclusion in the detailed process data section, namely I) Lurgi-fixed bed dry ash, 2) a slagging ash version of the Lurgi, and 3) the Westinghouse two stage fluidized bed system. Additional processes will be selected in the next reporting period.

\section{Process Data}

A second draft was prepared of the material collected for the Lurgi fixed bed dry ash gasifier. Work continued to collect information on a slagging ash version of the Lurgi gasifler. Two slagging gusifler programs are underway; one sponsored by the British Gas Corporation in England and another sponsored by the US ERDA at the Grand Forks (North Dakota) Energy Research Center. Advantages of the slagging version of the gasifier include:

(I) greater coal throughput and gas production

(a) less steam (which does not have to be used to prevent the ash from melting)

(3) Iess wastewater for treating

(4) more co formed and less tar by products

(5) more flexibility in coal feedstock

Dicadvantages of the slagging version include:

(1) more oxygen for combustion (and heat) since the higher temperature (greater heat content) slag stream is discharged

(2) restriction on certain coal having a high content of refractory ash which doco not mclt (olag) ad readily

Work began to obtain data on the Westinghouse two stage fluidized bed gasification system. This advanced system is intended for electric power generation and is being supported both by ERDA (about 2/3) and an industry team (ahmol 1/3).

Economic Considerations

Work began to review plant investment, operating cost, and other economic factors that could be used in comparing processes. 


\subsection{Direct Combustion}

H. 'I. Bowers, E. C. Fox, R. L. Simard

Part of the effort this past month was to prepare a revised project work statement. The scope of the revised work is to include an investigation into the restrictions to increased use of coal through direct combustion for small-medium industrial and large commercial/ residential applications.

A summary of present work to date has been prepared and is being forwarded to ERDA/FE OPPA for review. This will summarize the initial investigation into the technologies for the direct combustion of coal. This report is of a very preliminary nature, and very few conclusions can be drawn from the work accomplished to date. The technologies which are being developed to burn coal directly are outlined in the report and pertinent discussions are presented describing the technical questions associated with each, and the current research which is planned to answer' some of these questions. Finally, economic comparisons are presented for: these processes based on estimates in the current literature.

A critique was completed of the Council of Economic Priorities text "Power Plant Performance - Nuclear and Coal: Capacity Factors and Economics", and a draft report has been completed for transmittal to ERDA in early February. We are continuing our analysis of the FEA data base on power plant performance and a draft report is in preparation.

\subsection{Advanced Power Conversion Systems}

A. P. Fraas, **'M. E. Lackey, G. Samuels, A. S. Thompson**

Most of the effort this month was compiling information on ceramic : gas turbines and MHD systems, revising drafts of reports covering conventional and coal-fired gas turbines, * and compiling information on studies of advanced energy that were done during the past five to 10 years.

There were at least eleven studies to compare advanced energy systems between 1970 and 1976: The cost of these studies have ranged from about $\$ 100,000$ to $\$ 2,500,000$. A summary of these studies is given in Table 7.1.

The first such effort to arouse widespread interest was undertaken by the Electric Research Council in 1970. (The Council was an association of private and public electric utilities together with a representative from the Department of Interior.) A task force was set up in the fali: of 1970 to consider R\&D needs for the utility industry and report their recommendations. A comprehensive study was summarized in a report which included consideration of various advanced energy conversion systéms,

\footnotetext{
* To conform with the format requested by ERDA on January 12 . ** Consultant
} 


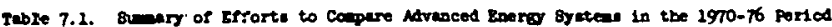

\begin{tabular}{|c|c|c|c|c|c|c|c|c|c|c|c|c|}
\hline Prien oponeor & 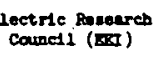 & 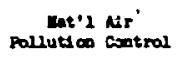 & $\infty$ & ISP & NeC & $\mathrm{Fx}$. & and & EPA & LROA- & ERDA- $\pi$ & exa & Exon \\
\hline 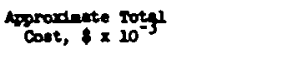 & 100 & 300 & 1000 & 200 & 1000 & $\infty$ & 100 & & & & 400 & 2500 \\
\hline oturo arous & INt Indeatry & 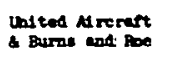 & cort. Agenes es & 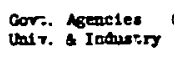 & $\begin{array}{l}\text { Cevet. Agencles } \\
\text { E Industry }\end{array}$ & 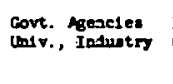 & $\begin{array}{l}\text { Induatry \& } \\
\text { cort. }\end{array}$ & $x$ & wate & 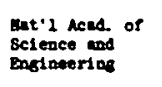 & c. E. & 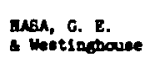 \\
\hline Bererence xo. of neport. & 1 & s & . & $2,6,7$ & 3 & 4 & & & & & & \\
\hline com tons for study & $\operatorname{RRC}$ & Insited as resart & $\infty \mathbf{T}$ & $\begin{array}{l}\text { Dixie Lee Rey } \\
\text { Repar:- }\end{array}$ & PpC & & & . & & & & ECAS \\
\hline Partios of studid & $1970-72$ & 1970 & 1972 & $19+2-7 \Xi$ & 1913 & $1923-74$ & $1974-77$ & 1975. . & $1575-75$ & $1976-77$ & $1976-77$ & $2975-76$ \\
\hline \multicolumn{13}{|l|}{ I0prove conventional } \\
\hline stem plent. & $x$ & $\mathbf{x}$ & & $\mathbf{x}$ & $\times$ & $x$ & $\times$ & & $x$ & $\times$ & $\mathbf{x}$ & $\mathbf{x}$ \\
\hline open cacio can rertine & $\mathbf{x}$ & $\mathbf{x}$ & 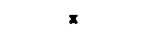 & x & $\mathbf{x}$ & $: \mathbf{x}$ & $\mathbf{x}$ & . & $\mathbf{x}$ & $x$ & $\mathbf{x}$ & $\mathbf{z}$ \\
\hline Comblom stem & $x$ & × & $x$ & $x$ & $x$ & : & $\mathbf{x}$ & & $\mathbf{x}$ & $x$ & $x$ & . \\
\hline Bottoniog acles & & $\mathbf{x}$ & . & $=$ & $\mathbf{x}$ & $x$ & $\times$ & 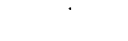 & $x$ & & $\times$ & $\mathbf{x}$ \\
\hline \multicolumn{13}{|l|}{ melear plents } \\
\hline 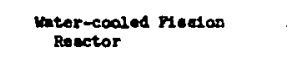 & $x$ & . & $x$ & $x$ & $\mathbf{x}$ & $x$ & $x$ & & * & & $x$ & 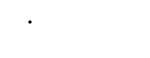 \\
\hline 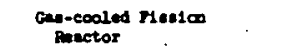 & $\mathbf{x}$ & & $\mathbf{x}$ & $x$ & × & $x$ & $x$ & & & & $\cdot$ & 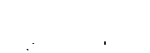 \\
\hline $\begin{array}{l}\text { malten ealt Plesion } \\
\text { Resector }\end{array}$ & $x$ & & $\times$ & $\mathbf{x}$ & $\times$ & $x$ & $x$ & & & & & . \\
\hline Larm & $\mathbf{x}$ & & $\mathbf{x}$ & $\mathbf{x}$ & $\times$ & $x$ & $\times$ & & $\mathbf{x}$ & & $\times$ & \\
\hline Palion Resectors & $x$ & & $\mathbf{x}$ & $\therefore$ & $x$ & & $\mathbf{x}$ & & & & & \\
\hline \multicolumn{13}{|l|}{ 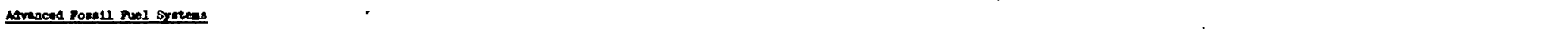 } \\
\hline Pol $\infty$ olls & $\mathbf{x}$ & & × & $x$ & $x$ & $\mathbf{x}$ & $x$ & & 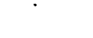 & $x$ & $\times$ & $x$ \\
\hline open cycle Nato - & $\mathbf{x}$ & & $\times$ & $\times$ & $\mathbf{x}$ & $\times$ & $x$ & $\cdot$ & & $\mathbf{x}$ & $\times$ & $\mathbf{x}$ \\
\hline Cloned Grele XFD & $\mathbf{x}$ & & $x$ & 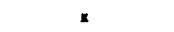 & $x$ & & $x$ & & &.$x$ & $x$ & $\mathbf{x}$ \\
\hline Cloaed cyele anes Turbioe & 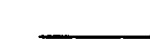 & $\mathbf{x}$ & $x$ & $\approx$ & $x$ & $x$ & $\times$ & & $x$ & $\times$ & $x$ & $\times$ \\
\hline$\underset{\text { Mrele }}{\text { Mell vapor Toppling }}$ & $x$ & $x$ & × & * & $x$ & $x$ & $\mathbf{x}$ & & $\mathbf{x}$ & $\times$ & $\times$ & $\mathbf{x}$ \\
\hline $\begin{array}{l}\text { gupereritical con } \\
\text { mentanse call. }\end{array}$ & $\dot{x}$ & 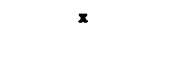 & $\mathbf{x}$ & : & $\times$ & $x$ & $\mathrm{x}$ & & $x$ & $x$ & $x$ & $\times$ \\
\hline \multicolumn{13}{|l|}{ soles, Mod, cootsemen, atc. } \\
\hline soler calle & $x$ & & $x$ & 8 & $x$ & $\times$ & $\mathrm{x}$ & & & & , & \\
\hline $\begin{array}{l}\text { Bolar vapor areles } \\
\text { posea coaveretere }\end{array}$ & $\times$ & & $x$ & x & $x$ & $\mathbf{x}$ & $x$ & & & & & \\
\hline monew & & & $\mathbf{x}$ & $\mathbf{x}$ & $x$ & & $x$ & & & & & \\
\hline 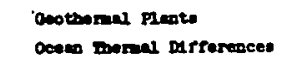 & 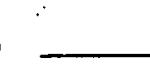 & & $\begin{array}{l}x \\
x \\
\end{array}$ & $\therefore$ & $\begin{array}{l}x \\
x \\
\end{array}$ & x & $\mathbf{x}$ & & & . & & \\
\hline \multicolumn{13}{|l|}{ mere 8tores brotine } \\
\hline nettiorie: & $\mathbf{x}$ & & $=$ & $=$ & $=$ & $\dot{x}$ & & & & & & \\
\hline $\mathrm{H}_{2}$ Produetion & $x$ & & $x$ & $x$ & $x$ & $\mathbf{x}$ & & & $\cdot$ & & & \\
\hline Coppreseed Ar Btoraco & & & & $\mathbf{x}$ & $x$ & $\mathbf{x}$ & & & & & & \\
\hline
\end{tabular}


References for Table 7.1

1. 'Eleçtric Utilities Industry Research and Development Goals Through the Year 2000, ERC Publ. No. 1-71, Report of the R\&D Goals Tásk Force to the Electric Research Council, June 1971.

2. A Program of Research; Development and Demonstration for Enhancing Coal Utilization to Meet National Energy Needs, CMU/NSF-RANN Workshop on Advanced Coal Technology, October 1973.

3. The Nation's Energy Future, WASH-1281; Submitted by Dr. Dixy Lee Ray to Richard M. Nixon, President of the United States, December 1, 1973.

4. Evaluation of R\&D Projects, Report of the FPC Technical Advisory Committee on Energy Conservation, 1974.

5. F. L. Robson et al., Technological and Economic Feasibility of Advanced Power Cycles and Methods of Producing Nonpolluting Fuels for Utility Power Stations, PB 198 392, United Aircraft Research Laboratories, East Hartford, Connecticut, December 1970 :

6. Summary Report of Engineering Foundation Conference on Energy Technologies for the Future, held at Saxtons River, Vermont, July 24, through July 27, 1972.

7. Energy Research Priorities Conference, Berwick Academy, South. Berwick, Maine, July 30 - August 4, 1972.

8. G. P. Cooper, Energy Conversion Research - An assessment of Need : in the U.S. A., ASME Paper 76-WA/RGPC-6, Consolidation Coal Company, December 1976. 
improved means for transmission and distribution of electric power, environmental problems, energy utilization, and general problems of industry growth and system development. The report included estimates of the funding required for the various R\&D projects recommended but did not include specific estimates for the thermal efficiency, capital cost, or cost of electrical power for the various advanced energy conversion systems considered. This report was widely circulated.

Concurrently with the Electric Research Council effort outlined above, the National Air Pollution Control Administration funded a study at United Aircraft to consider means for reducing air pollution and at the same time increase the efficiency of fossil fuel-fired power conversion systems. In this study estimates were made of the thermal efficiency, capital cost, and cost of electricity likely to be associated with the advanced power conversion systems considered.

The Electric Research Council report led to a proposal by electric utilities that they form an association to carry out the R\&D effort recommended in the task force report. To do this they needed a change in the rate setting practice of the Federal Power Commission which up to that time prevented them from including costs for R\&D work when setting up their rates to consumers. The question then arose in washington as to whether the utilities should be permitted to do this or whether the Federal Government should impose a tax on electric power consumption and use the proceeds for a government-managed R\&D effort. To provide a more detailed basis for appraising the relative merits of the multitude of possible R\&D efforts, the office of Science and Technology launched a comprehensive study in January of 1972 by setting up a set of task forces composed of people from the Bureau of Mines, NASA, the Department of Interior, the Bureau of Standards, etc., in an effort to appraise the feasibility of the various advanced systems, their thermal efficiency, capital costs, cost of electricity, cost of the developmental program, and their respective effects on the environment and the consumption of natural resources. Each task force (usually made up of advocates of particular systems) tendered their reports to OST in the summer of 1972 . These reports were then reviewed critically by a panel of experts and the results of the task force work together with the evaluation by the review panel were summarized in a report prepared at the Brookhaven National Laboratory. The distribution was very limited.

In the summer of $19 / 2$ the ivational science Foundation intiated a series of workshops in which the various aspects of the national enerey situation were examined by groups made up of representatives from industry, government, and the universities. These included a one-week workshop at Saxtons River, Vermont, that covered essentially all aspects of the energy situation. A second one-week conference at Berwick, Maine, was devoted to problems of the electric utilities. A third held in June 1973 was concerned with the utilization of coal. Other smaller conferences were devoted to more specialized questions including fission reactors solar power, geothermal, oceanthermal differences, etc. In each case the agenda consisted of presentations by advocates of particular advanced systems, pleas or 
demands made by members of environmentalist organizations, statements on legal or financial problems made by experts in those areas, estimates of mineral reserves made by university or government geologists and by men from the petroleum and mining industries, etc., and then the group as a whole discussed these presentations. Et'forts were then made to arrive at some sort of consensus which included both majority and minority opinions. Reports covering the first three workshops were published but the reports covering the later, smaller workshops did not get beyond, the draft stage.

In 1973 in response to a Presidential request, Dixie Lee Ray, then Chairman of the Atomic Energy Commission, set up a set of task. forces similar to that set up by OST in 1972. Greater emphasis. was given in this set of studies to means for energy conservation than was the case in the OST study. The report, known as the: Dixie Lee Ray report, was widely disseminated and was a major factor in Federal Government plans that culminated in the establishment of ERDA.

Essentially concurrent with the Dixie Lee Ray study, the Federal Power Commission established a committee of representatives from government agencies, universities, and industry to appraise the potential of advanced systems for use by the electric utilities. . Both the study and the resulting report placed their prime interest on the amount of fuel oil that might be saved as a consequence of the development of each of the advanced systems considered.

In 1974 in response to an express request from the President of the United states, the ASME set up a task force to consider the relative merits of advanced energy conversion systems. A committee of about 40 ASME members from both industry and government was set up; a series of meetings were held at which brief presentations were made by advocates of advanced systems, and their relative merits were discussed by. the experts on the committee. Efforts' to arrive at a reasonable consensus proved difficult but a report was prepared, approved by the ASME policy Board, and Council, and a paper summarizing this report was presented at the ASME Winter Annual Meeting in December, 1976. The work of this group is continuing.

In 1974 an effort to obtain a more definitive study than any made to date was initiated by representatives of NSF, OMB, and OCR. This led to a well-funded study carried out under the detailed supervision of NASA Lewis Laboratory which let contracts to General. Electric and Westinghouse. While NASA did some comparative work in-house, General Electric and Westinghouse followed a set of ground rules arrived at through conferences with NSF, OCR, and NASA and made an effort to prepare quite detailed. estimates of the thermal efficiency, capital cost, cost of electricity, and program developmental costs for advanced fossil energy systems for utility applications. This work was completed by the latter part of 1976. Note that the role played by OCR when the project was launched initially was continued by ERDA-FE. The resulting reports have been widely circulated. 
In 1976 EPRI decided that the ECAS study ought to be extended to include nuclear systems, hence they funded the General Electric Company to apply the same ground rules as used in the ECAS study to similar estimates for nuclear plants. This study is to be completed by about March of 1977.

In 1975 ERDA-FE funded a study at MITRE which was similar to the ECAS study but was aimed primarily at program planning and was substantially less comprehensive. A report covering this study was prepared and a few copies printed for internal use at ERDA in the summer of 1976.

Early in 1976 ERDA-FE arranged for the National Academy of Science and Engineering to appraise the problems of extracting and utilizing fossil fuels, particularly coal. The prime concern was with coal mining, conversion to gaseous and liquid fuels, and direct combustion. The relative merits of advanced power conversion systems were also considered, particularly from the standpoint of the combustion system. A report has been prepared that is in draft form and is undergoing review as of January, 1977.

EPA launched a study in 1976 to evaluate the various advanced energy conversion systems employing fossil fuel. This study is being carried out by personnel at M.I.T. and Exxon Research Laboratory. A report is to be issued in 1977. Particular attention is being given in this study to the technical feasibility of various advanced concepts.

A tentative schedule for the completion of the topical reports and summary report of our current study is given below. The dates shown for completion of drafts are the dates the reports are to be sent to ERDA for review.

Report Eubjcct

Alkali Metal Rankine

Conventional Gas Turbine

Coal-Fired Gas Turbine

Ceramtc Gas Turbine

Water" Cooled Gas Thurbine

Fuel Cells

Open Cycle MHD

Combined Cycled

ronse. Cyste Fas Thirbine

Closed Cycle MHD
Draft Date

December 6, 1976

February 28, 1977

February 28, 1977

March 15, 1977

March 31, 1.977

April 15, 1977

April 30, 1977

May 31, 1977

May 31, 1977

June 30, 1977 
Report Subject

Supercritical $\mathrm{CO}_{2}$

Conventionai steam.

Summary Report
Draft Date

July. 31, 1977

July 31, 1977

August $30, .1977$

\subsection{Liquefaction}

This work is being performed under subcontract to the Ralph M. Parsons Company. J. B. O'Hara is the Project Manager for the Ralph M. Parsons Company.

A preliminary work plan and schedule was prepared to define the activities and methods by which the evaluation efforts will be performed. The work plan basically divides the work into five specific tasks to meet the scope of work outlined by the contract. The first four tasks are scheduled for completion by March 31, 1977. They cover the screening to establish the most promising processes and recommendations as to what processes/technologies should be emphasized. It also covers the establishment of data format, technical and economic ranking.techniques.

The fifth task, to be completed by september 30, 1977, is to perform a detailed analysis of the most promising technologies and to recommend action where appropriate.

An initial list of approximately 50 candidate liquefaction processes was prepared. Information is being gathered, as necessary, on the various processes.

\subsection{High Btu Gasification}

A subcontract for this work is being negotiated.

\subsection{Gas Cleanup Studies \\ M. S. Edwards}

The literature search for gas cleanup processes was completed. Correspondence with process vendors is continuing; the Benfield Corporation supplied additional information on the Benfield process, Allied Chemical Corporation was queried on the Selexol process, and Union Carbide Corporation on the applicability of molecular sieves. Responses from the latter two are expected soon. : Additional vendors will also be contacted for more detailed process information, based on the results of a process screening effort currently in progress. This screening study is expected. to result in five to ten processes considered most applicable" to low Btu gasification and In Situ gasification. 
of the more than fifty processes initially reviewed, thirty-four were compiled for further screening. These processes are being subjected to reasonable technical and environmental criteria. These criteria currently appear to narrow the field to about fifteen possible processes. These results are expected to be finalized by the end of February. Subsequently, a more detailed review will limit the candidate processes to fewer than ten. Detailed technical descriptions of these candidates will be provided, along with process economics culled from the literature search and vendor contacts.

Review of high temperature particulate control required in advanced power systems (specifically, pressurized fluid bed combustors) is underway. A list of vendors and developers was developed and contacts will be initiated soon. 'l'he literature search is essentially complete at this time.

\subsection{Benet'ireiation}

G. R. Peterson and Suman P. Singh

The following items have been completed:

1. Flow sheets for the mechanical coal beneficiation facilities for both the 1,500 TPD and 15,000 TPD plant size.

2. Flow sheets, material balances and capital costs for the Battelle Hydrothermal Coal Process (BHCP) for the 15,000 TPD plant size.

3. Block flow diagrams for the TRW-Meyers Process (TRW), the Ledgemont Oxygen Leaching Process (LOL), and the SURC Chemical Comminution Frocess (EURC).

The following items are currently being developed:

1. Process descriptions for the TRW, LOL and SURC coal beneficiation processes.

2. The PRP computer program at ORNL is being adapted for performing the economic analysis for the various coal beneficiation processes.

3. Procter derlgn for lhe BHCP for the 1,500 TPD plant kize.

\subsection{In Situ Coal Gasification}

W. C. Ulrich and G. J. MacKenzie

G. J. MacKenzie joined the project technical staff on a full-time basis in January. He has been assigned the task of preparing the summary and detail data source sheets for the candidate in situ coal gasification processes. 
The fourteen base cases assembled last month were reduced to six for evaluating in situ gasification process on a regional basis. Because of the varieties of coal types and resource configurations represented in the western region of the United States, it was divided into three subregions. These three subregions plus the three other main regions of. the U.S. (easterm, north central, and south central) make up the six cases. A representative or predominant coal type was: selected in each of the six regions, and determination of the regional champion in situ gasification processes is proceeding on schedule. A draft of the report listing the regional champions with reasons for the choices is expected to be completed for review by the end of. February. Summary data source sheets containing information on processes that is already available will also be assembled in draft form by the end of February.

The literature review is essentially complete; however, the acquisition of reports and papers, especially translations of Russian work, is continuing.

\subsection{Potential for the Synthesis of Chemicals from Coal and Oil Shale}

The Radian Corporation is working under subcontract on this study. D. N. Garner is the Project Director for the Radian Corporation. This study consists of the following tasks:

Task I - Survey the sources of primary feedstocks currently used for chemicals production restricting this to chemicals that could be produced from coal. Tabulate current annual quantities of primary sources of feedstocks and project to the year 2000 .

Task 2 - Identify the impediments to the utilization of existing commercial-scale coal conversion technology to produce chemical feedstocks by a) examining at least one case of the successful replacement of a feedstock in the chemical process industry, and $b$ ) examining existing technology in light of those factors identified in Task $2(a)$ above.

Task 3 - Determine whether the ERDA program as outlined at present will a) meet projected feedstock requirements, or b) overcome the impediments identified in Task 2.

Task 4 - Suggest any program reorientation or program supplements necessary to meet deficiencies identified in Task 3 and establish the considerations behind each suggestion.

Task 5 - A summary final report will be prepared which describes in detail all of the information obtained during the program and which will document all of the conclusions reached. 
A work plan was prepared and the effort on Task 1 was initiated.

Task Status

Thirty chemicals have been identified as primary feedstocks and data on their production volumes have been gathered. This information is given in Table 7.2. Task 1 is considered complete, assuming no chemicals are added to the primary feedstock list. Projected chemical production volume information will no longer be actively sought from. the literature or industry sources, although revisions might certainly occur as a result of data gathering efforts on future tasks. 
TABLE 7.?

PRIMARY FEEDSTOCKS WITH PAST

AND PROJECTED PRODUCTION VOLUMES

Production

1975

Chenical

Armonia

Ethylene

Benzene

Propylene

Ethylene Dichloride

Toluene

Methanol

Xylene

Ethylbenzene

Terephthalic Acid

Formaldehyde

Styrene

Vinyl Chlorine

Ethylene Oxide

Ethylene Glycol

Carbon Black

Butadiene

p-Xylene

Acetic Acid

amene

Cyclohexane

Phenol

Acetone

Isopropanol

Propylene Docide

Acetic Anhydride

Adipic Acid

Ethamol

Acrylonitrile

Vinyl Acetate

\section{Billions of lbs.}

31.56

19.78

. 7.66

7.60

5.94

5.87

5.18

5.08

4.72

4.65

4.62

4.40

4.20

3.94

3.80

2.76

2.65

2.43

2.10

1.97

1.77

1.72

1.59

1.57

1.52

1.47

1. 36

1. 29

1.22

1.14
Average
$1969-1974$

$4.2 \%$

7.4

5.0

6.3

5.0

6.5

10.3

16.0

3.0

13.7

5.9

5.0

8.9 .

2.7

3.9

2.4

3.2

10.5

5.0

11.2

1.0

6.6

6.3

$-1.0$

8.2

0.3

4.3

$-4.4$

$--$

14.0
Armual 1974-1975

$-.02 \%$

$-17.1$

$-29.8$

$-27.5$

$-35.2$

$-12.0$

$-24.7$

$-12.2$

$-22.0$

8.9

$-19.9$

$-26.2$

$-25.4$

1.2

13.7

$-17.7$

$-28.2$

$-10.4$

$-18.8$

$-32.1$

$-24.6$

$-25.1$

$-19.6$

$-18.9$

$=13.3$

$-9.9$

$-8.1$

$-20.1$

$-14.0$

$-19.0$
Production 1975-2000 Billions of lbs.

\section{$3.9 \%$}

6.6

6.7

7.8

7.0

3.8

7.4

7.1

7.8

8.5

7.4

7.8

7.5

7.0

5.4

3.9

4.0

9.2

6.4

8.0

7.0

7.8 .

6.0

3.0

9.1

0.5

7.5

1.5

7.9

8.3 .
82.13

97.50

38.48

49.75

32.24

15.05

30.55

28.00

30.86

35.74

27.53

28.77

25.62

21.38

14.15

7.21

8.45

21.75

9.90

13.49

9.61

11.25

6.82

3.29

13.60

1.66

8.29

1.87

8.16

8. 37 


\section{FOSSIL ENERGY ENVIRONMENTAL PROJECT}

C. R. Boston

\subsection{Program Plan}

The draft program plan delivered to FE/MFPM on December 8, 1976, has now been accepted as final.

\subsection{Environmental Incluslons in RFPs}

M. S. Salk

No further work on this draft document is anticipated until comments are received from ERDA. In the meantime, however, MFPM plans to use this draft document in upcoming contracts for pipeline gas demonstration plants and FE's Division of Environmental and Socioeconomic Programs will use it in preparing Environmental Development Plans.

\subsection{Landfill Storage of Solid Wastes}

\section{H. M. Braunstein}

This task is about one week behind schedule. Drafts of all sections of the landfill document have been submitted, and, except for minor additions or changes, the writing can be considered finished. Content editing is complete for Sects. 2, 4, and 5 and is in progress for Sects. 1 and 3. Thus, subtask 4 (document preparation) is complete and the program is in subtask 5 (document review and finalization). The manpower expenditure in January amounted to 6.3 MMs.

\subsection{Environmental Monitoring Handbook}

M. S. Salk

In the month of January an expanded outline was prepared for cach section of the baseline monitoring portion of the handbook by the responsible individuals. The first draft of these outlines was discussed in a general meeting of the people involved to discover overlaps between sections and to better coordinate the document. The outlines were then revised on the basis of this discussion and were distributed to people outside the FEEP for comment and criticism. The outlines were revised taking these comments into consideration and will serve as the basis for writing the document. Substantial work has been done on the socioeconomic section, where drafts have been prepared of some sections and fairly detailed outlines have been prepared for others. Total time spent of the project in January was $1.6 \mathrm{MMs}$. A slip of about one week in subtask 2 (detailed outline preparation, Part 1) is expected. However, this is not expected to delay the Part 1 completion date of April 15. 


\subsection{Programmatic EIS-Pipeline Gas}

L. H. Stinton

Approximately 1.5 Ms was put on this task during the reporting period, mainly on subtasks 1 ( (literature search) and 2 (outline preparation). This document is expected to fill the existing gap between previous, generic statements and future, site-specific statements. By focusing on only a few of the more probable, surrogate site/process combinations we hope to do a more detailed assessment of impacts. 


\section{COAL-FUELED MIUS}

R. S. Holcomb and W. R. Mixon

This project for analysis, design, and demonstration of a concept utilizing a fluidized-bed coal combustion system as a heat source for a gas turbine generator suitable for applications in Modular Integrated Utility Systems (MIUS) is carried out under the ORNL-HUD-MIUS Program within the Energy Division. Work is supported by the U.S. Department of Housing and Urban Development under HUD Interagency Agreement No. IAA-H-40-72 and by the Energy Research and Development Administration, Office of Fossil Energy (formerly Office of Coal Research, Department of the Interior), under ERDA Contract No. E(49-18)-1742. The project consists of four phases: I - Conceptual Preliminary Evaluation; II - Conceptual DesIgn; III - Detailed DesIgn and Construction; and IV - Shakedown, Performance, and Endurance Tests.

\subsection{Coal Metering and Feed Systems}

A solution to the flow imbalance problem in the coal feed system was achieved and the system was placed on automatic operation early this month. It ran continuously for the remainder of the month without incident, and about 400 hours of automatic operation have been accumulated.

\subsection{Supplemental Studies}

The final FluiDyne report on corrosion test operations was not received, but enough test data and preliminary results were forwarded to permit selection of the specimens to be sectioned for metallographic examination. Sample tubes to be used for calibration of eddy current scanning tests were prepared, and eddy current tests were scheduled for next month.

A draft report on tests of heat transfer from a fluidized bed to air-cooled tubes within the bed was completed and distributed for review. The heat transfer coefficient was found to be in the range of 80 to 90 $\mathrm{Btu} / \mathrm{hr}-\mathrm{ft} \mathrm{t}^{2}{ }^{\circ} \mathrm{F}$ above a fluidizing velocity of about $1.4 \mathrm{ft} / \mathrm{sec}$ as sompared to a value of $50 \mathrm{Btu} / \mathrm{hr}-\mathrm{ft}^{2}-{ }^{\circ} \mathrm{F}$ assumed for the design of the ORNL furnace. This high value of heat transfer coefficient is attributed to the small mean particle size $(\checkmark 460 \mu \mathrm{m})$ used in the low-velocity range as compared to the larger particle size employed in other furnace designs. 


\section{ANALYTICAL CHEMISTRY}

W. R. Laing and L. J. Brady

A total of 54 samples were submitted for analysis during the month.

Samples of two coal-derived liquids were tested for simulated boiling range. Plots of the percent eluted vs the boiling point were delivered to the engineer who submitted the samples.

Proximate and ultimate analyses were made on 11 samples consisting of coal or char.

Moisture, ash, carbon, and sulfur were determined on tar samples from hydrocarbonization run $\mathrm{HC}-10$. The moisture was separated by azeotropic distillation.

Carbon monoxide, nitrogen, methane, and carbon dioxide were determined on 35 gas samples produced by in situ-gasification tests.

\section{CHEMICAL RESEARCH}

L. M. Ferris.

This work is reported quarterly.

\section{LIFE SCIENCES}

C. W. Gehrs

This work is reported quarterly. 
THIS PAGE

\section{WAS INTENTIONALLY LEFT BLANK}


INTERNAL DISTRIBUTION

\author{
1. S. I. Auerbach \\ 2. M. Bender \\ 3. N. E. Bolton \\ 4. C. R. Boston \\ 5. R. E. Brooksbank \\ 6. C. H. Brown \\ 7. G. H. Burger \\ 8. D. A. Canonico \\ 9. J. A. Carter \\ 10. B. R. Clark \\ 11. H. D. Cochran, Jr. \\ 12. E. Copenhaver \\ 13. F. L. Culler \\ 14. R. M. Davis \\ 15. D. G. Doherty \\ 16. M. S. Edwards \\ 17. D. M. Eissenberg \\ 18. J. L. Epler \\ 19. G. G. Fee \\ 20. D. E. Ferguson \\ 21. L. M. Ferris \\ 22. R. C. Forrester III \\ 23. W. Fulkerson \\ 24. W. R. Gambili \\ 25. R. B. Gammage \\ 26. D. A. Gardiner \\ 27. C. W. Gehrs \\ 28. J. B. Gibson \\ 29. W. L. Greenstreet \\ 30. M. R. Guerin \\ 31. C. W. Hancher \\ 32. L. A. Harris \\ 33. S. E. Herbes \\ 34. J. R. Hightower \\ 35. S, r. Hildehrand \\ 36. R. S. Holcomb \\ 37. J. M. Holmes \\ 38. J. K. Huffstetler \\ 39. C. L. Hunt \\ 40. G. R. Jasny, $Y-12$ \\ 41. R. L. Jolley \\ 42. J. E. Jones \\ 43. D. S. Joy \\ 44. ก. L. Keller \\ 45. R. T. King \\ 46. W. R. Laing \\ 47. R. S. Livingston
}

48. R. E. MacPherson

49. A. P. Malinauskas

50. G. B. Marrow

51. C. J. McHargue

52. L. E. McNeese

53. J. R. McWherter

54. H. J. Metz

55-57. W. R. Mixon

58. J. E. Mrochek

59. P. Nettesheim

60-64. J. P. Nichols

65. L. C. Oakes

66. G. R. Peterson

67-68. T. W. Pickel

69. W. W. Pitt

70. H. Postma

71. D. E. Reichle

72. C. R. Richmond

73. B. R. Rodgers

74. M. W. Rosenthal

75. T. H. Row

76. W. L. Russe11

77. R. Salmon

78. G. Samuels

79. C. D. Scott

80. D. S. Shriner

81. W. D. Shults

82. S. P. N. Singh

83. C. B. Smith

84. G. P. Smith

85. I. Spiewak

86. R. L. Spore

87. E. G. St. Clair

88. J. B. Storer

89. R. A. Strehlow

90. 0. K. Tallent

92. A. J. Thompson

93. D. B. Trauger.

94. W. C. Ulrich

95. P. R. Vanstrum

96. J. S. Watson

97. J. R. Weir

98. P. R. Westmoreland

99. M. K. Wilkinson

100. L. V. Wilson

101. R. G, Wymer

102. C. S. Yust 
103. Patent office

104. Lab. recurds

105-111. Lab. Records

112-114. Central Research Library

115. Document Reference Section

EXTERNAL DISTRIBUTION

ERDA, Oak Ridge Operations

116. Research and Technical Support Division

ERDA, San Francisco Operations

117. N.S. Hagen

ERDA, Washingt on

118. W. Bakker, MER

119. N. F. Barr, DTO

139. T. K. Lau, MFPM

120. J. D. Batchelor, Cill

121. R. Beck, CCU

140. R. W. A. LeGassie, APA

122. T. Beresovski, RD\&D

141. J. L. Liverman, AES

123. L. M. Burman, OGST

142. W. G. McDaniel, MFPM

124. E. L. Clark, CCU

143-148, C. Miller, CCU

125. N. P. Cochran, MFPM

149. G. A. Mil1s, FER

150. W. E. Mott, DBER

126. T. Cox, FER

127. P. Duhame 1, FER

128. J. Forst, FER

129. H. Frankel, FER

130. S. I. Freedman, CCU

151. M. B. Neuworth, CCU

152. E. S. Pierce, DPR

153. H. E. Poda11, MFPM

154. J. L. Powe11, MFPM

155. J. W. Ramsey, OGST

131. D. Garrett, MFPM

156. M. Reilly, FE/OPPA

132. S. W. Gouse, AFE

157. John Shen, FER.

133. W. S. Harmon, MFPM

158. A. P. Sikr1, OGST

134. K. M. Jimeson, DTO

13y. D. K. Stevens, DPR

135. H, R. Johnson, FE/OPPA

160. J. W. Watkins, OGST

136. H. Jones, MFPM

137. L. Kindley, FER

161. H. C. White, AFE

138. C. Knudsen, FE/OPPA

162. P. R. Wieber, OGST

163. R. W. Wood, DBER ,

Department of Housing and Urban Development, 451 th Street, S.W., Washington, DC 20410

164. G. S. Leighton

165. J. H. Rothenberg

National Science. Fnundation, $1800 \mathrm{G}$ Streel, N.W., Washington, DC 20550

166. R. S. Goor

167. Robert Rabin

University of Kentucky, Institute for Mining and Materials Research, 213 Bradley Ha11, Lexington, KY 40506

168. Theresa Wiley, Institute Librarian

169. 0. J. Haun

170. J. K. Shau 
171. William E. Pepelko, U.S. Environmental Protection Agency, ETRL, 1055 Laillow, Cincinnati, OH 45237

172. Charles B. Sedman, U.S. Environmental Protection Agency, Research Triangle Park, NC 27711

173. N. S. Boodman, Section Supervisor, U.S. Steel Corporation Applied Research Laboratory, 125 Jamison Lane, Monroeville, PA 15146

174-185. ERDA Pittsburgh Energy Research Center, U.S. Energy Research and Development Administration, Attention: Director for J. P. Barreca, 4800 Forbes Ave., Pittsburgh, PA 15213

186-191. The Director, Morgantown Energy Research Center, P.0. Box 800, Morgantuwn, WV 26506

192. Tetra Tech, Inc., 1911 N. Ft. Myer Drive, Suite 601, Arlington, VA 22209, Attention: Walter McGough, Jr.

193. Cameron Engineers, Attn: Gary L. Baughman, 1315 South Clarkson St., Denver, CO 80213

194-220. Technical Information Center, ERDA 